TMD DISCUSSION PAPER NO. 80

FREE TRADE AGREEMENTS AND THE SADC ECONOMIES

Jeffrey D. Lewis

The World Bank

Sherman Robinson

International Food Policy Research Institute

Karen Thierfelder

U.S. Naval Academy

Trade and Macroeconomics Division International Food Policy Research Institute 2033 K Street, N.W. Washington, D.C. 20006, U.S.A.

November 2001

TMD Discussion Papers contain preliminary material and research results, and are circulated prior to a full peer review in order to stimulate discussion and critical comment. It is expected that most Discussion Papers will eventually be published in some other form, and that their content may also be revised. This paper was written under the IFPRI project "Macroeconomic Reforms and Regional Integration in Southern Africa" (MERRISA), which is funded by DANIDA (Denmark) and GTZ (Germany). This paper is available at: http://www.cgiar.org/ifpri/divs/tmd/dp.htm 
Trade and Macroeconomics Division

International Food Policy Research Institute

Washington, D.C.

TMD Discussion Paper No. 80

\title{
Free Trade Agreements and the SADC Economies
}

\author{
Jeffrey D. Lewis \\ Sherman Robinson \\ Karen Thierfelder
}

November 2001

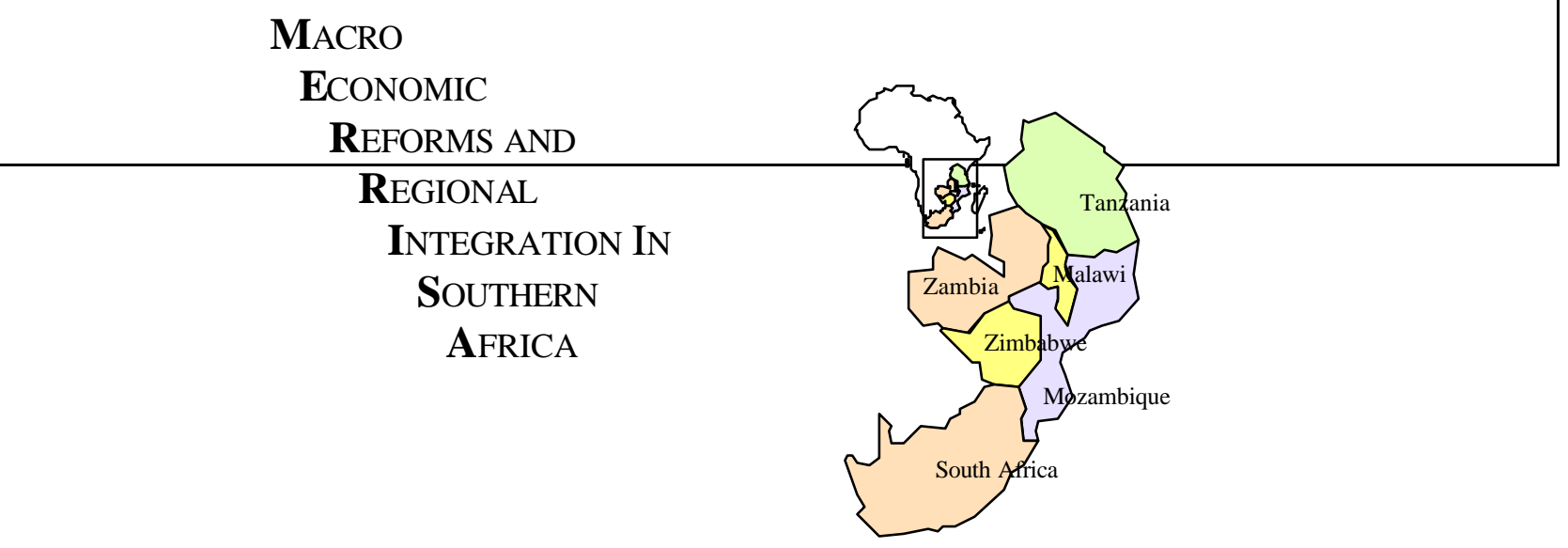




\begin{abstract}
Countries in Southern Africa have engaged in a variety of trade liberalization initiatives. For example, South Africa and the European Union (EU) negotiated a free trade agreement (FTA) in 1999. The EU unilaterally opened its markets to the least developing countries, which includes some of the countries in the region, in 2001 under its "Everything But Arms" (EBA) initiative. Although not formally established, countries in the region have discussed a SADC FTA. In this paper, we use a multi-country, computable general equilibrium (CGE) model to analyze the impact of trade liberalization on countries, sectors, and factor. To focus on trade flows among countries in Southern Africa, the model includes seven countries in the region (South Africa, Botswana, Malawi, Mozambique, Tanzania, Zambia, and Zimbabwe), the rest of SADC, the rest of Sub-Saharan Africa, and five other aggregate regions (the EU, High-Income Asia, Low-Income Asia, North America, and the rest of the world). First, we analyze the FTA between South Africa and the EU. Then, we consider how the rest of Southern Africa might respond: (1) by enforcing a SADC FTA; (2) by exploiting advantages of unilateral access to the EU in addition to a SADC FTA; and (3) by entering an FTA with the EU and other SADC countries. We find that trade creation dominates trade diversion for the region under all FTA arrangements. Some SADC economies are slightly hurt by the FTA between the EU and South Africa while others slightly gain. Overall, the agreement is not a beggar thy neighbor policy. Unilateral access to the EU is more beneficial, in terms of real GDP and real absorption, for SADC countries than a SADC FTA. However, reciprocal reforms, under an EU-SADC FTA dominate unilateral access to the EU because they require more structural adjustment. Finally, we find that South Africa is not large enough to serve as a growth pole for the region. Access to EU markets provides substantially bigger gains for the other SADC countries than access to South Africa.
\end{abstract}




\section{Table of Contents}

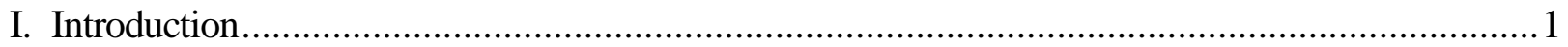

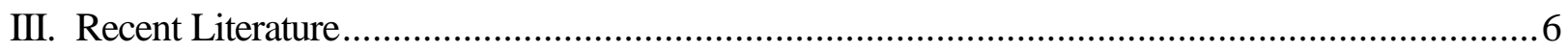

IV. The Southern Africa CGE Model ........................................................................... 8

V. Southern Africa Model Results ..................................................................................... 13

1. SADC countries on the periphery of trade reform: EU-SACU FTA................................13

2. SADC countries and regional trade initiatives: EU-SACU FTA \& SADC FTA....................15

3. SADC countries and trade relations with the EU: EBA vs. EU-SADC FTA....................... 16

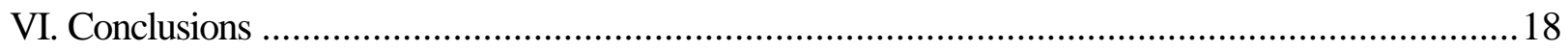

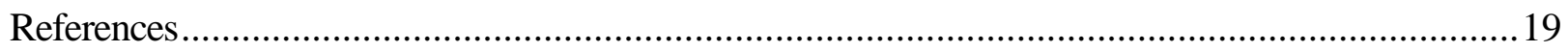

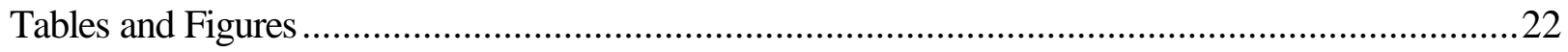

List of Discussion Papers......................................................................................... 45 


\section{Introduction}

Countries in Southern Africa have engaged in a variety of trade liberalization initiatives. For example, South Africa and the European Union (EU) negotiated a free trade agreement (FTA) in 1999, after more than two years of contentious negotiations. Because of South Africa's predominance in the subregion, the implementation of this agreement will have an impact on trade flows in the rest of Southern Africa. The South Africa-EU FTA will also affect other regional trade initiatives. It has strained discussions over the formation of a free trade area within the Southern African Development Community (SADC), of which South Africa is a prominent member. ${ }^{1}$ It also raises questions regarding the continuing viability of the South African Customs Union (SACU) arrangement by which customs revenues are shared amongst South African and its smaller neighbors (Botswana, Lesotho, Namibia, and Swaziland).

Independent of these regional trade agreements, some of the SADC countries have access to EU markets under the EU's "Everything But Arms" (EBA) Initiative, approved in February 2001. The EBA initiative provides full access to the EU markets for the world's 49 Least Developing Countries, which includes the SADC countries Lesotho, Malawi, Mozambique, Tanzania, and Zambia. The EU has removed tariffs and quotas on most imports except arms. The three exceptions - sugar, bananas, and rice- have a longer phase out period ${ }^{2}$

In addition to participating in regional trade agreements, countries in Southern Africa are also members of the World Trade Organization (WTO) and therefore have an interest in multilateral tariff negotiations. Prior to the WTO, developing countries were often at the periphery - OECD countries set the agenda for multilateral tariff reforms and the interests of developing countries were considered only after the major countries reached agreement on their issues. To be effective members of the next WTO round of negotiations, developing countries must be able to evaluate the economic consequences of different WTO proposals. Developing countries also need to create alliances with respect to their main export and import commodities and the markets they approach for their exports. Countries in Southern Africa do not have a unified negotiating position in multilateral negotiations. While there is debate over the effectiveness of regional trade blocks in multilateral negotiations, Crawford and Laird (2001) note that the interests of least developed countries, particularly those in Sub-Saharan Africa, are ignored by the emerging mega-blocs of regional trade agreements.

While the eventual configuration of trade agreements in Southern Africa will be driven by a variety of political considerations as well as negotiated outcomes, it is also useful to provide some quantitative benchmarks against which different arrangements can be compared. In his paper we analyze the various regional integration and liberalization arrangements recently agreed to or currently under consideration.

\footnotetext{
${ }^{1}$ The Southern African Development Community (SADC) includes Angola, Botswana, Democratic Republic of Congo, Lesotho, Malawi, Mauritius, Mozambique, Namibia, Seychelles, South Africa, Swaziland, Tanzania, Zambia, and Zimbabwe.

${ }^{2}$ See Bjornskov and Krivonos (2001) for a more detailed discussion of the impact of the EBA Initiative on developing countries.
} 
We focus on the following issues:

(1) What are the impacts of the EU-South Africa Free Trade Agreement (FTA) on trade welfare, and economic structure in South Africa and the rest of Southern Africa?

(2) Should the rest of Southern Africa respond with regional trade initiatives and on what terms?

(3) What are the benefits of unilateral access to the EU for the SADC countries that qualify for the EBA Initiative?

(4) Can South Africa serve as a growth pole for the region?

We approach these questions using a multi-country, computable general equilibrium (CGE) model to analyze the impact of trade liberalization on countries, sectors, and factors. Our model consists of fourteen linked country/region models. To focus on trade flows among countries in Southern Africa, we have seven countries in the region (South Africa, Botswana, Malawi, Mozambique, Tanzania, Zambia, and Zimbabwe), the rest of SADC, the rest of Sub-Saharan Africa, and five others (European Union, High-Income Asia, Low-Income Asia, North America, and Rest of World). Each country model has seventeen sectors and two labor types, and is linked to all other countries through explicit modeling of bilateral trade flows for each traded sector.

We use the model to simulate a series of alternative scenarios, starting with the impact on the EU and South Africa of the recently signed FTA between those two countries. Then we consider how the rest of Southern Africa might respond: (1) by enforcing a SADC FTA, in essence creating a hub and spoke arrangement in which the SADC region and the EU are spokes and South Africa is the hub; (2) by exploiting the advantages of unilateral access to the EU markets made available under the EU's EBA initiative; or (3) by entering an FTA with the EU and South Africa as equal partners. In the later case, those countries that participate in the EBA would be providing reciprocal access for the EU in their own markets.

It should be stressed that our empirical results should not be interpreted as "predicting" or "forecasting" what the different alternatives will bring. As will be evident, our representation of the different possible arrangements will be quite crude. For example, in the EU-South Africa free trade scenario, we assume all tariffs between the two economies are immediately set to zero, rather than phased in over time and with some exclusions; we also make no attempt to capture the other dynamic effects that should be associated with such an agreement, such as increased investment flows, changing production technologies, or skill upgrading. We focus instead on understanding the impact on trade, production, and resource allocation that might occur if different changes in tariff structures were imposed.

The next section provides an overview of the economic structure, trade linkages, and protection structure among the countries used in the model. Section three presents the main feature of the Southern Africa CGE model. We discuss empirical results in section four. Section five presents the conclusions. 


\section{Economic Structure and Trade Patterns}

Macroeconomic data for the regions in our Southern Africa simulation model are presented in table $1 .{ }^{3}$ There are enormous differences in size, the role of trade, and factor endowments among the regions. As seen in figure 1a, South Africa is the prominent economy in the region - it accounts for almost 76 percent of SADC GDP, followed by the rest of SADC which accounts for 8 percent of regional GDP. ${ }^{4}$ The other countries in the region are quite small, each accounts for less than 5 percent of regional GDP. However, South Africa (and Africa in general) is small compared to other major trade partners for the region, as seen in figure 2a. A similar pattern holds for exports - South Africa is the major exporter among the SADC countries, but it is small in the global market when compared to the $\mathrm{EU}$ (figures $1 \mathrm{~b}$ and $2 \mathrm{~b}$ ).

SADC countries are more dependent on trade than is the EU. At the extreme, exports are 58 percent of GDP for Botswana and 52 percent of GDP for the rest of SADC (see table 1). In contrast, the EU exports 14 percent of its GDP. A similar pattern holds for imports as a share of GDP. This high trade dependency means that trade liberalization can induce large structural changes in South Africa and the rest of Southern Africa.

Characteristic of developing countries, the SADC countries (with the exception of South Africa and Botswana) have a high share of labor in agriculture (see table 1). The extreme example is Tanzania where 55 percent of the labor force is employed in agriculture; the share also large for Mozambique (43 percent) and Malawi (33 percent). South Africa and Botswana are more like the EU; all have approximately 3 percent of the labor force employed in agriculture. The SADC countries (with the exception of South Africa and Botswana) also have a high share of unskilled labor in the total labor force.

There are sizeable differences in the production structures among the SADC countries, as well as between the individual SADC countries and the EU (see table 2). With the exception of South Africa and Botswana, primary products (an aggregate of grains, fruits \& vegetables, other agriculture, livestock, and forestry \& fisheries) are quite important for the SADC countries (see table 2). They account for as much as 31 percent of the value of output in Tanzania, 29 percent in Malawi, and 24 percent in Mozambique. In contrast, primary products account for only 4 percent of the value of output in South Africa and 2 percent in Botswana. The later two SADC countries are more like the EU in which primary products account for only 3 percent of the value of output. Food processing also is an important sector for many of the SADC economies, particularly Tanzania (16 percent), Zimbabwe (12 percent), Zambia, Malawi, and Mozambique (11 percent each). Mining is an important sector for

\footnotetext{
${ }^{3}$ The data set is aggregated from the GTAP 1997 data set, final version 5.0. For model regions that are made up of more than one national economy, all figures on exports and imports reported in these tables (and used in the model) refer to trade with economies outside that region, and thus exclude trade that occurs among members of the same region. In constructing the regional data sets, this "within region" trade is netted out and treated as another source of domestic demand.

${ }^{4}$ In the database, there are seven individual countries that are members of SADC - South Africa, Botswana, Malawi, Mozambique, Tanzania, Zambia, and Zimbabwe. All other SADC countries are in the region, "rest of SADC". In the text, "rest of SADC" refers to the later region; "Southern Africa" refers to all SADC countries.
} 
Botswana (28 percent) and the rest of SADC (21 percent), reflecting natural resource and mineral endowments in those countries. Machinery and equipment production is a low share of output in many of the SADC countries with the extreme being Mozambique ( 0.7 percent of the value of total output). South Africa and Botswana have a higher share (9 and 7 percent, respectively) and are closer to the EU where machinery and equipment are 15 percent of the value of total output.

International trade theory generally identifies two different types of international trade. Trade among developed industrial countries with similar endowments and technology is largely "intraindustry," with high exports and imports within sectors, whereas trade between high and low-income economies (with very different factor endowments and technological processes) is largely inter-industry, with more sectoral specialization. ${ }^{5}$ With a tremendous range in factor endowments and income levels between the SADC economies and other economies in the model, particularly the EU, there is ample scope for Heckscher-Ohlin forces (based on different factor endowments and comparative advantage theory) to influence trade.

Trade shares are consistent with intuition about international comparative advantage. For example, 38 percent of total exports from the EU are in machinery \& equipment, 17 percent are in intermediates, and 32 percent are in services (see table 3). There is evidence of two-way trade in machinery \& equipment as each sector accounts for 32 and 29 percent of total imports, respectively (see table 4).

In the SADC countries, trade patterns are consistent with the Hechscher-Ohlin model. For all countries, machinery \& equipment and basic intermediates are a large share of total imports (see table 4). In general, machinery \& equipment are small shares of total exports as well, with the exception of South Africa and Botswana where there is some evidence of two-way trade in these goods (see table 3). Basic intermediates, a sector comprised of mineral products, ferrous metals, and other metals are also important export sectors for some SADC countries such as Zambia (57 percent of the value of exports), South Africa (40 percent), and Zimbabwe (20 percent). These high export shares are consistent with the endowment of natural resources in those countries.

Typical of developing countries, many of the countries in the region have high shares of primary products in total exports - 69 for Malawi, 46 for Tanzania, 39 for Zimbabwe, and 18 for Mozambique. Food processing is an important export commodity for Mozambique where it is 26 percent of the value of total exports. Parts of southern Africa is rich in natural resources. Reflecting this, export shares of energy and minerals are high for Botswana (75 percent of the value of total exports), the rest of SADC (60 percent), and South Africa (12 percent). In Botswana and the rest of SADC, a large share of production of energy and minerals is exported ( 99 and 90 respectively).

Most general equilibrium analyses of regional economic liberalization focus on the removal of $a d$ valorem equivalent price distortions against imports that arise from existing trade barriers and other

\footnotetext{
5“Intra-industry" in this context refers to the two-way trade between industries that produce commodities that are similar in input requirements and highly substitutable in use, such as similar televisions manufactured by different producers.
} 
sources. This is also the primary focus of the simulations conducted in this paper, since the pattern and degree of protection are important determinants of the impacts of trade liberalization. The larger the initial trade distortion, the greater structural adjustment will be when that distortion is removed. Table 5 presents ad valorem import protection (tariff plus NTB) rates by sector and country of origin for nonservice sectors for the regions that are the main focus of our analysis - the EU, South Africa, Botswana, Malawi, Mozambique, Tanzania, Zambia, Zimbabwe, and the rest of SADC.

Import protection rates vary substantially by sector and source of imports. South Africa protects apparel (with rates varying from 31 percent against the rest of SADC to 13 percent against Mozambique), textiles (ranging from 20 percent against Malawi to 10 percent against rest of SADC) and food processing (ranging from 100 percent against Malawi to 49 percent against Tanzania). South Africa has a high trade weighted average tariff against Malawi (21 percent), Tanzania (20 percent), and Mozambique (19 percent). Its average tariffs against other SADC countries range from 0 to 10 percent. It also has a relatively low average tariff against the EU at 8 percent. However, in certain sectors, the tariff rates against EU imports are quite high: 71 percent for food processing, 39 percent for grain, 26 percent for apparel and 26 percent for fruits and vegetables.

With the exception of Botswana and South Africa, which have eliminated bilateral tariffs, intraSADC tariff rates are high and uneven across countries in the region. The highest average tariff rate against another SADC country ranges from 94 percent (Zimbabwe against imports from Tanzania) to 20 (Zambia against imports from Malawi). Zimbabwe has the highest average tariff rates against other SADC countries, ranging from 12 percent against imports from Malawi to 94 percent against imports from Tanzania. Mozambique faces zero tariffs when it sells to most countries in the region (Botswana, Malawi, Zambia, and rest of SADC). Average tariffs in the region against imports from the EU range from 8 percent (South Africa) to 24 percent (rest of SADC).

Certain sectors in the region have high tariffs, for example, food processing in Botswana (70 percent against Zimbabwe and 67 percent against the EU); apparel in Malawi (41 percent against South Africa and 42 percent against Zimbabwe); food processing in Mozambique ( 50 percent against Tanzania); apparel in Zimbabwe (80 percent against South Africa, 100 percent against Rest of SADC, and 55 percent against the EU); and apparel in the Rest of SADC (58 percent against South Africa and 35 percent against the $\mathrm{EU})$.

The EU protects processed foods and fruits \& vegetables from imports from SADC countries. The EU tariffs on processed foods range from a low of 29 percent against Mozambique to 86 percent against Botswana. In the fruits \& vegetable sector, EU tariffs range from 14 percent against Malawi to 63 percent against Tanzania. In general, the EU provides better access to its markets for the SADC countries, than those countries do for the EU - with the exception of Mozambique, the EU has a lower average tariff against each SADC country than that country has against the EU.

All SADC countries depend heavily on the EU for export sales (see figure 3). Botswana has the highest dependence, selling 76 percent of its exports to the EU (primarily diamonds in the mining sector). Other SADC countries send between 28 percent (Zambia) and 39 percent (Malawi and 
Mozambique) of their total exports to the EU. Despite its relatively low export dependence on the EU, Zambia depends on the EU for certain commodity sales: it sells 94 percent of its fruits \& vegetables, 90 percent of its textiles, and 85 percent of its processed food to the EU. The other SADC countries also depend heavily on EU markets for the sale of their processed food, textile, apparel and fruits \& vegetables.

SADC countries are less dependent on South Africa than on the EU as a market for their exports (see figure 4). The export shares to South Africa range from 0.4 percent for the rest of SADC to 13 percent for Botswana and Zimbabwe.

There is little trade among the SADC countries, with the exception of South Africa being an important destination for exports. Interestingly, Zimbabwe is the next most important country in the region, following South Africa, for all SADC countries. However, the export market shares to Zimbabwe are small, ranging from 0.2 percent for the Rest of SADC to 3.2 percent for Botswana

\section{Recent Literature}

The recent proliferation of regional trade initiatives in all parts of the world, including Southern Africa, has revived the debate over the benefits of RTAs versus multilateral tariff reform. Panagariya (2000) surveys the theoretical work, describing changes in trade creation and trade diversion under various assumptions about market structure and the welfare effects of other dynamic changes. Both Panagariya's survey and the early work on customs unions indicate that whether or not an RTA benefits its members depends on parameter values and initial economic structure - it is essentially an empirical issue that must be settled by analysis of data. Robinson and Thierfelder (1999) survey the empirical literature in which multi-country CGE models have been used to analyze the impact of regional trade agreements. The multi-country CGE models differ widely in terms of country and commodity coverage, assumed market structure, policy detail, and specification of macroeconomic closure. In spite of these differences, surveys of these models support two general conclusions about the empirical effects of RTAs: (1) in aggregate, trade creation is always much larger than trade diversion; and (2) welfare measured in terms of real GDP or equivalent variation - increases for member countries.

In this paper, we evaluate various types of RTAs for countries in Southern Africa as well as multilateral tariff reduction. Other empirical studies of regional trade options for Southern Africa consider similar issues:

(1) What are trade creation and trade diversion effects of regional trade agreements (either with the EU or among SADC countries)?

(2) What impact do FTAs have on non-member countries in the region?

(3) What effect do global tariff reductions, as agreed to in the Uruguay round, have on Southern Africa? 
Tsikata (1999) uses a partial equilibrium model of trade creation and trade diversion to measure import changes following an intra-SADC RTA. She focuses on the fiscal impact of an RTA by calculating revenue changes. Not surprisingly, she finds that countries with high trade dependence and high initial tariffs also experience the highest revenue losses from an RTA. South Africa, in contrast, does not depend on the region for trade and consequently would have a small revenue loss from an RTA.

CGE analyses of various FTAs in Southern Africa also emphasize changes in trade creation and diversion. The general conclusion is that trade creation dominates trade diversion. ${ }^{6}$ Davies (1998) — using GTAP data and modeling framework - simulates a FTA between the EU and South Africa and finds strong potential trade diversion following an FTA. He bases this conclusion on a discussion of pre-FTA tariff rates. Since South Africa had lower tariffs on the EU than other sources, he asserts that the other producers have lower costs so the FTA caused a switch from cheaper sources to less-efficient EU products. Andriamananjara and Hillberry (2001), also use the GTAP framework to evaluate the EU-South Africa FTA. They find evidence of both trade creation and trade diversion. In their analysis, South Africa's trade with the EU expands, while trade with other trade partners falls, consistent with Davies' discussion of trade diversion. However, Andriamananjara and Hillberry conclude that the net effect is trade creating as South Africa's exports and imports both increase. Andriamananjara and Hillberry's analysis extends beyond the static allocative efficiency effects of a FTA. They incorporate dynamic effects of trade and growth, adding estimates of the links between trade openness and total factor productivity shocks for South Africa. They find that the trade-induced growth is $2 \%$ of total growth over the phase-in period ${ }^{7}$

Evans (2001) evaluates trade options for SADC countries - an FTA, a customs union, or open regionalism, by which SADC countries extend tariff reductions to all countries on a MFN basis. He finds that trade creation dominates trade diversion in an FTA as intra-SADC trade increases by 9 percent while trade with the rest of the world hardly changes. With free trade, there is also trade creation as SADC trade expands by nearly 7 percent, but there are potential terms of trade costs. Under "high" export price elasticities, he finds that the welfare gain from free trade exceed those under an FTA. ${ }^{8}$ Davies (1998) also describes the effect an FTA between South Africa and the EU has on the rest of Southern Africa. He finds that the rest of Southern Africa suffers as its trade volumes decline. ${ }^{9}$

Hertel et al. (1998) evaluate the effects on Africa of tariff reductions in manufactures, textile and clothing, and agriculture tariffs agreed to under the Uruguay Round. Like Davies, they use the GTAP data and modeling framework. ${ }^{10}$ They find that the limited gains from the Uruguay Round in Africa are

\footnotetext{
${ }^{6}$ This result is consistent with other studies of regional trade trade agreements, see Robinson and Thierfelder (1999).

${ }^{7}$ They use the dynamic version of GTAP which uses growth projections to simulate future base models.

${ }^{8}$ However, these results are sensitive to export price elasticities. Under "low" export elasticities, welfare gains are higher with an FTA and there are actually welfare losses with free trade in SADC countries.

${ }^{9}$ As will be discussed below, we find that an FTA between the EU and SACU has mixed results for the other SADC countries.

${ }^{10}$ Since tariffs will be reduced by 2005 , they first project the model forward using growth rates in relative resource endowments (population, unskilled labor, capital stock, skilled labor and productivity). This becomes the base model.
} 
mainly due to the fact that Africa does not ease its trade restrictions as much as other countries, so world trade "bypasses the continent." Textiles and apparel will be hurt most by the Uruguay Round. In contrast there will be a slight expansion of production of cereals, non-grain crops, and forestry and fish products. The production increase in the latter two products is projected to be sold in Asia, suggesting exports will become more diversified, rather than concentrated in Europe. They then simulate domestic reforms in both the trade and transportation sector and in food grain productivity. They note that in both sectors, "Africa lags significantly behind other low-income countries, and institutional reforms could provide major gains at low cost" (p. 229).

Lewis, Robinson and Thierfelder (1999) ask similar questions about the effects of regional and multilateral trade agreements in Southern Africa using a more aggregated version of the model than the one used here. The data for that model is for 1995 from GTAP version 4. They focus on the interaction between three countries: the EU, South Africa, and the Rest of Southern Africa (an aggregate of Botswana, Malawi, Mozambique, Tanzania, Zambia, Zimbabwe and the Rest of SADC). They find that (1) trade creation dominates trade diversion in the EU-South Africa FTA and that other SADC countries benefit from the agreement and (2) the Rest of Southern Africa does better with a trilateral FTA with the EU rather than global tariff liberalization of 50 percent. The later result reflects the Rest of Southern Africa's high trade dependence on the EU and the EU's high initial trade barriers against the EU. See Lewis (2001) for a summary of this work and trade analysis of the region in more sectoral detail.

Similar to the analysis in this paper, McDonald and Walmsley (2001) evaluate the effects of the EU-South Africa FTA on other countries in the region. They focus on the effects the agreement will have on Botswana. We take a broader perspective and discuss the effects for all other SADC countries, including Botswana. ${ }^{11}$ Walmsley and McDonald find that Botswana gains due to both allocative efficiency and terms of trade improvements. As will be discussed below, we also find gains for Botswana and other SADC countries following the EU-South Africa FTA. ${ }^{12}$

\section{The Southern Africa CGE Model}

We analyze regional integration in Southern Africa using a multi-country computable general equilibrium (CGE) model. Such models are designed to quantify many of the economic forces accompanying regional integration that are considered in international trade theory. ${ }^{13}$ The Southern Africa model we have developed is in the tradition of recent multi-country CGE models developed to

\footnotetext{
${ }^{11}$ McDonald and Walmsley (2001) and this study use GTAP v5 database which has detailed data for the countries in southern Africa.

${ }^{12}$ In an earlier version of this paper, we found that Botswana was worse of following tariff elimination between the EU and South Africa, in contrast to McDonald and Walmsley (2001). Our differences arose from different experiment design and the use of different versions of the database.

${ }^{13}$ For a discussion of the analytic and modeling issues related to analysis of free trade areas, see Baldwin and Venables (1995) and Winters (1996). Robinson and Thierfelder (1999) summarize the findings from empirical models of regional integration.
} 
analyze the impact of the Uruguay Round of GATT negotiations and the impact of the North American Free Trade Agreement. ${ }^{14}$

The model developed in this paper consists of a multi-regional CGE framework containing a seventeen sector, fourteen-region, general equilibrium model, where the regional CGE models are interconnected through trade flows. ${ }^{15}$ For the purpose of describing the model, it is useful to distinguish between the individual "country" models and the multi-region model system as whole, which determines how the individual country models interact. When the model is actually used, the within country and between country relationships are solved simultaneously.

The model database consists of social accounting matrices (SAMs) for each country, including data on their trade flows. ${ }^{16}$ The development of a consistent multi-country database is itself a major task; for our model, we rely on version 5.0 the GTAP database. The SAM starts from multisectoral input-output data, which are expanded to provide information on the circular flow of income from producers to factors to "institutions," which include households, enterprises, government, a capital account, and trade accounts for each partner country, and for the rest of the world. These institutions represent the economic actors whose behavior and interactions are described in the CGE models. The parameter estimates for the sectoral production functions, consumer expenditure functions, import aggregation functions, and export transformation functions are estimated from base-year data and other econometric sources. The various parameters used in the model represent point estimates for the base year (1997) and the model was benchmarked so that its base solution replicates the base data.

Each sub-regional or "country" CGE model follows closely what has become a standard theoretical specification for trade-focused CGE models. ${ }^{17}$ In addition to seventeen sectors for each country model, the model has five factors of production (two labor types, land, natural resources, and capital). For each sector, the model specifies output-supply and input-demand equations. Output supply is given by constant elasticity of substitution (CES) functions over value added, while intermediate inputs are demanded in fixed proportions. Profit-maximization by producers is assumed, implying that each factor is demanded so that marginal revenue product equals marginal cost. However,

\footnotetext{
14 These models, in turn, have built on multi-country models developed to analyze the impact of the Tokyo Round of GATT negotiations - in particular, the multi-country CGE model developed by Whalley (1985). Our model starts from the WALRAS model developed at the OECD to analyze the impact of the current GATT negotiations on the major OECD countries (OECD, 1990) and the RUNS model described in Goldin, Knudsen, and van der Mensbrugghe (1993). Starting from a single country model of the U.S., Robinson et al. (1993) expanded the model to include Mexico for analysis of NAFTA. Other versions of the model are described in Lewis, Robinson, and Wang (1995), Lewis and Robinson (1996), and Hinojosa-Ojeda, Lewis, and Robinson (1995).

${ }^{15}$ The model also permits regional interactions through endogenous migration of capital and labor, but for all experiments presented in this paper, this feature is not used. See Hinojosa-Ojeda, Lewis, and Robinson (1995) for analysis of a Greater North America Free Trade Area (GNAFTA) using a similar model that includes labor migration.

${ }^{16}$ Social Accounting Matrices are described in Pyatt and Round (1985).

${ }^{17}$ Robinson (1989) surveys CGE models applied to developing countries. Shoven and Whalley (1984) survey models of developed countries. The theoretical properties of this family of trade-focused CGE models are discussed in Devarajan, Lewis, and Robinson (1990).
} 
factors need not receive a uniform wage or "rental" (for non-labor factors) across sectors; sectoral factor market distortions are often imposed that fix the ratio of the sectoral return to a factor relative to the economy-wide average return for that factor.

In common with other CGE models, the model only determines relative prices and the absolute price level must be set exogenously. In our model, the aggregate consumer price index in each subregion is set exogenously, defining the numeraire. The advantage of this choice is that solution wages and incomes are in real terms. The solution exchange rates in the sub-regions are also in real terms, and can be seen as equilibrium price-level-deflated (PLD) exchange rates, using the country consumer price indices as deflators. ${ }^{18}$ Countries and regions in the model are linked by trade flows. We choose value foreign trade in North American dollars, and therefore fix the exchange rate for North America. In effect, foreign trade is valued in the prices of the numeraire country which we assign to be the North America region. World prices are converted into domestic currency using the exchange rate, including any tax or tariff components. Cross-trade price consistency is imposed, so that the world price of country A's exports to country B are the same as the world price of country B's imports from country A.

Each "country" model traces the circular flow of income from producers, through factor payments, to households, government, and investors, and finally back to demand for goods in product markets. The country models incorporate tariffs which flow to the government, and non-tariff revenues which go to the private sector. ${ }^{19}$ Each economy is also modeled as having a number of domestic market distortions. There are sectorally differentiated indirect, consumption, and export taxes, as well as household and corporate income taxes. The single aggregate household in each economy demands commodities with fixed expenditure shares, consistent with optimization of a Cobb-Douglas utility function.

One implication of including these varied existing distortions, which capture in a stylized way institutional constraints characteristic of the economies, is that policy choices must be made in a secondbest environment. In our simulations involving the establishment of FTAs, we are not considering scenarios which remove all existing distortions. Existing taxes and factor-market distortions are assumed to remain in place, along with existing import barriers against the rest of the world. In this second-best environment, economic theory gives little guidance as to the welfare implications of forming a FTA.

Sectoral export-supply and import-demand functions are specified for each country. In common with other CGE models (both single and multi-country), the Southern Africa CGE model specifies that goods produced in different countries are imperfect substitutes. At the sectoral level, in each country, demanders differentiate goods by country of origin and exporters differentiate goods by

\footnotetext{
${ }^{18}$ De Melo and Robinson (1989) and Devarajan, Lewis, and Robinson (1993) discuss the role of the real exchange rate in this class of model.

${ }^{19}$ The country models do not explicitly model revenue constraints in the government sector. This may be an important issue for developing countries which depend on tariff revenue to finance government expenditure. In this model, we assume government savings adjust.
} 
destination market. Composite demand is for a translog aggregation of sectoral imports and domestic goods supplied to the domestic market. Sectoral output is a CET (constant elasticity of transformation) aggregation of total supply to all export markets and supply to the domestic market. Allocation between export and domestic markets occurs in order to maximize revenue from total sales.

The rest of the world is treated like any other region in the model - with explicit production, consumption, and trade behavior in a separate regional CGE model. This is an extension of earlier versions of the model which represented the rest of the world as simply a supplier of imports to and demander of exports from the other model regions as a group. As the country coverage in the model expands - and correspondingly, the rest of the world shrinks - it is less plausible to build a model with an implicit "large" rest of the world. Instead, we allow downward sloping import demand for each region and upward sloping export supply curves from the rest of the world to each region.

For many single-country and multi-country models, a lack of detailed econometric work forced modelers to use simple functional forms, with few parameters, for the import-aggregation and exporttransformation functions. The common practice is to use a constant elasticity of substitution (CES) function for the import aggregation equation, which is a very restrictive functional form and has led to empirical problems. ${ }^{20}$ As a result of these limitations, modelers have begun to explore other formulations, while maintaining the fundamental assumption of product differentiation. In this model, we have used a flexible specification of the demand system called the almost ideal demand system (or AIDS). ${ }^{21}$ The AIDS specification allows non-unitary income elasticities of demand for imports and also pairwise substitution elasticities that vary across countries. We exploit the later feature of the AIDS specification and allow high elasticity of substitution between each SADC country and the EU as well as among the SADC countries. This allows imported commodities from these regions to be good substitutes with the each other and the domestic variety, dampening the market power attributed to individual countries in a model in which commodities are differentiated by country of origin (Armington assumption).

We capture certain stylized features of labor markets in developing countries in the model. In South Africa and other SADC countries, there is high unemployment, suggesting a readily available supply of labor. We therefore assume there is a fixed wage in these countries and that the labor supply is endogenous to clear the market. When sectors expand, they can meet labor demands at the given wage by attracting workers who were not in the labor market (as well as attracting workers from contracting sectors). For other countries and factors, we assume that factor markets (including labor)

\footnotetext{
${ }^{20}$ Armington (1969) used the specification in deriving import-demand functions, and the import aggregation functions are sometimes called Armington functions. Devarajan, Lewis, and Robinson (1990) discuss in detail the properties of single-country models which incorporate imperfect substitution. Brown (1987) analyzes the implications of using CES import aggregation functions in multicountry trade models. Others have criticized the use of the CES function on econometric grounds. See, for example, Alston et al. (1989).

${ }^{21}$ Hanson, Robinson, and Tokarick (1993) use the AIDS function in their 30-sector single-country CGE model of the U.S. They estimate the sectoral import demand functions using time-series data and find that sectoral expenditure elas ticities of import demand are generally much greater than one in the U.S., results consistent with estimates from macroeconometric models.
} 
clear. In these markets, while sectoral employment changes, aggregate employment is held constant; instead, wages adjust.

In addition, we represent production features unique to mining, an important sector for many countries in Southern Africa. Since output changes can occur only in the long-run when new mines are discovered, we assume inputs to the sector are fixed. This also keeps output constant.

The Southern Africa CGE model, like other multi-country CGE models, has a medium to longrun focus. We report the results of comparative static experiments in which we "shock" the model by changing some exogenous variables and then compute the changed equilibrium solution. We do not explicitly consider how long it might take the economy to reach the new equilibrium, or what other adjustments (such as investment changes, technology transfer, productivity shifts, etc) might occur as well. The model's time horizon has to be viewed as "long enough" for full adjustment to occur, given the shock. While useful to understand the pushes and pulls the economies will face under the creation of an FTA, this approach has obvious shortcomings. In particular, it does not consider the costs of adjustment, such as transitional unemployment, that might occur while moving to the final equilibrium.

Given the medium to long-run focus of the analysis, the model incorporates a simple macro closure that does not account for any short-run adjustment mechanisms (such as Keynesian multipliers). In each regional model, aggregate real investment and government consumption are assumed to be fixed proportions of aggregate GDP. The trade balance in each region is also assumed fixed (with the real exchange rate adjusting to equilibrate aggregate exports and imports), so domestic savings are assumed to adjust to achieve macro equilibrium.

Our model has a number of features that are different from a "standard" GTAP model (Hertel, 1997). First, the use of sectoral export supply functions in each regional model (using CET functions) provides a treatment on the export side that is symmetric with the treatment of imports as imperfect substitutes with domestically supplied goods (the "Armington assumption" for specifying import demand functions). The standard GTAP model only assumes imperfect substitutability on the import side, which implies that domestic prices of exportables are very sensitive to foreign demand and changes in world markets. For exploring trade liberalization scenarios, the resulting model tents to generate unrealistically large terms-of-trade effects.

Second, the use of AIDS rather than CES import demand functions allows a more flexible treatment of degrees of substitutability between goods originating from different types of countries. In a model focusing on trade with very poor developing countries, the more flexible functional form is especially useful.

Third, the standard GTAP model specifies a macro closure in which regional trade balances vary endogenously. In our model, regional trade balances are assumed fixed. Specifying fixed trade balances seems better in a model focusing on the impact of trade liberalization, where it is desirable to abstract from issues of short-run macroeconomic adjustment. 
Fourth, the standard GTAP model specifies the exchange rate as the numeraire in each regional CGE model, while we specify a consumer price index as a numeraire in each region. Since all these models solve only for relative prices, the choice of numeraire is largely a matter of convenience. In models in which regional trade balances at equilibrium are not zero, it is important to note that they are defined in the prices of the numeraire country (in our case North America).

\section{Southern Africa Model Results}

We present a series of scenarios in which trade becomes more liberalized. We begin with an FTA scenario between the EU, South Africa, and Botswana in which we eliminate all bilateral tariffs and non-tariff barriers (EU-SACU FTA). ${ }^{22}$ We include Botswana in the FTA because both Botswana and South Africa are members of SACU and it may be difficult to differentiate goods from those two countries.

Next, we consider the response for the rest of Southern Africa. One option would be to create a SADC FTA in conjunction with the EU-SACU FTA. In essence South Africa becomes the hub and the EU and the other SADC countries as a group are the two spokes. Rules of origin are always an important component of an FTA, which, by definition, does not enforce a common external tariff against non-FTA members. When SADC countries form an FTA, it is possible for non-FTA countries to gain access to South Africa via other SADC countries, if they face low tariffs when entering the other SADC countries. To evaluate how important rules of origin may be for trade and welfare in the SADC FTA, we consider two types of SADC customs unions in which all SADC countries eliminate tariffs among themselves and maintain a common external tariff, eliminating the need for countries to address rules of origin. At one extreme, we assume SADC countries impose the lowest external tariff as the common external tariff by sector. At the other extreme, we assume the SADC countries impose the regional average tariff by sector as the common external tariff. This will indicate how important rules of origin are for trade and welfare in the SADC FTA.

Finally, we consider the interaction between the other SADC economies and the EU, the most important trade partner for each country in the region. We consider the benefits of unilateral access to EU markets for those countries that qualify for the EBA initiative. Then, we consider the effects of a more aggressive trade strategy in the region - an FTA with all SADC countries and the EU. In effect, the countries eligible for unilateral access to the EU must reciprocate and allow EU products in to their markets duty-free.

\section{SADC countries on the periphery of trade reform: $E U-S A C U$ FTA.}

We find that an FTA between the EU, South Africa, and Botswana has a much bigger impact on Botswana and South Africa than on the EU (see figure 5). Real absorption increases by 1.7 percent and 4.6 percent for South Africa and Botswana respectively. Real GDP increases by 1.7 and 2.5 percent for South Africa and Botswana respectively (see figure 6). The real GDP gains for each country

\footnotetext{
${ }^{22}$ We eliminate tariffs in a single scenario. In practice the tariffs between the EU and South Africa will be phased in over a twelve year period. See Andriamananjara and Hillberry (2001), table 3, for an estimate of the tariff reductions over this time period.
} 
reflect an increase in the labor supply as well as allocative efficiency. The supply of unskilled labor increases by 2.8 percent for South Africa and 11.6 percent for Botswana (see figure 7). The EUSACU FTA results in a dramatic increase in total exports for each of these countries (see figure 8).

In contrast the EU experiences only slight gains with its real absorption increasing by .03 percent, real GDP increasing by .002 percent, and total exports increasing by .45 percent. These lopsided gains reflect differences in trade dependences. Botswana depends quite heavily on the EU with 76.3 percent of total exports going to the EU (see figure 3). The dependence is particularly strong for commodities such as mining (96.5 percent), processed food (61.2 percent), livestock (55.3 percent), and fruits and vegetables (28.3 percent). While the EU has a trade weighted average tariff of 1.7 percent against imports from Botswana, the tariff is quite high for some commodities such as processed food (86.3 percent) and fruits and vegetables (25 percent).

While not as extreme as Botswana, South Africa is also heavily dependent on EU export markets, with 35.4 percent of total exports going to the EU. The dependence is especially strong for commodities such as livestock (71.4 percent), fruits and vegetables (71.6 percent), other agriculture (38.6 percent), food processing (41.8 percent) and mining (48.2 percent). While the EU's tradeweighted average tariff against South Africa is low (4.0 percent) the EU has high tariffs against certain products from South Africa. For example, it is 44.1 percent on processed food and 17.2 percent on fruits and vegetables.

In contrast, the EU sends almost none of its exports to Botswana and only 1.2 percent to South Africa. The EU's largest export share to South Africa is 6.0 percent in the energy and mineral sector. The next highest export market shares to South Africa are machinery \& equipment and basic intermediate goods, each at 1.6 percent. While South Africa has high tariffs on processed food (71.4 percent), grain (38.8 percent), and fruits \& vegetables (25.5 percent) from the EU, South Africa is not an important market the for the EU in these products; each has less than 1.5 percent of EU export market share for that sector.

With the EU-SACU FTA, trade creation dominates trade diversion for each FTA member (see figures 9-11). For South Africa and the EU, there is no absolute trade diversion only relative trade diversion as exports to FTA members increases more than the increase in exports to non-FTA members. For Botswana, which is extremely dependent on the EU markets, there is some trade diversion as exports to non-FTA members decline slightly.

Total exports from South Africa to the EU increase by 23 percent, with particularly large relative gains in formerly protected sectors. For example, processed food exports increase by 275 percent (removing the 44 percent tariff), fruits \& vegetables by 107 percent (removing the 17 percent tariff), and apparel by 52 percent (removing the 7 percent tariff). ${ }^{23}$ Total exports from Botswana to the

\footnotetext{
${ }^{23}$ These large quantity changes are consistent with the high elasticity of substitution between imports and the domestic variety in the AIDS import demand equation. Sensitivity analysis on the elasticity of substitution shows that the trade response is lower and the price effect is higher when the elasticity of substitution is low. In addition, we allow an endogenous supply of unskilled labor which magnifies the output response to a policy shock.
} 
EU increase by 10 percent with the biggest gains to sectors that faced high tariffs: processed food, grain, and fruits \& vegetables. Exports from the EU to South Africa increase by 27.2 percent and to Botswana by 74 percent (this is from a very low base).

The EU-SACU FTA has only a small impact on the other SADC countries. Some, such as Tanzania, Zimbabwe and the Rest of SADC experience slight losses in terms of real absorption (figure 5) and real GDP (figure 6). The others - Malawi, Mozambique, and Zambia - have a slight increase in real GDP. As a result of the EU-SACU FTA, all SADC countries export less to South Africa who substitutes goods from the EU for goods from SADC countries. All SADC countries export slightly more to the EU. Zimbabwe, which experiences the largest loss, is the most dependent on South Africa and therefore suffers the most from South Africa's switch in preferences. ${ }^{24}$

\section{SADC countries and regional trade initiatives: EU-SACU FTA \& SADC FTA.}

Given the EU-SACU FTA, the other SADC countries can respond by establishing a SADC FTA parallel to the EU-South Africa FTA, creating a "hub and spoke" FTA, in which South Africa is the hub and the EU and other SADC countries as a group are the spokes. As seen in figures 3 and 4, South Africa is an important export destination for other SADC countries (although it is not as important as the EU) and these countries face fairly high tariffs in South Africa.

Real GDP increases for all SADC countries following the formation of a SADC FTA in conjunction with the EU-SACU FTA. The biggest gainers are Botswana, Zimbabwe and Malawi. These countries have the highest export dependency in South Africa (see figure 3). Zimbabwe and Malawi also face the highest tariff in South Africa, suggesting potential gains from a regional trade agreement. Interestingly, Botswana gains substantially when it participates in both the SADC FTA and the EU-SACU agreement. It already has access to South Africa and it depends has the highest export share with the EU. The gains come from structural adjustment following liberalized trade with other SADC countries - Botswana has much higher tariffs against its SADC trade partners than those countries have against Botswana (see table 5). Consistent with the structural adjustment changes, this scenarios results in the largest increase in the unskilled labor supply (see figure 7).

With any FTA, rules of origin can be a problem since non-FTA members have incentives to enter the high-tariff country indirectly via the low-tariff country. Following the formation of a SADC FTA, non-member countries could gain access to South Africa via the other SADC countries. While it is difficult to know how the proposed agreement would address domestic content and rules of origin issues, we consider the sensitivity of our trade and welfare results to two extremes. In each case, we

\footnotetext{
${ }^{24}$ In an earlier analysis of free trade within the region, Lewis, Robinson, and Thierfelder (1999), we found that the EU-SACU FTA was not a "beggar thy neighbor policy". Instead, the entire region, "rest of SADC" gained slightly. In this analysis, we have more detailed data and disaggregate Malawi, Mozambique, Tanzania, Zambia, and Zimbabwe from the region "rest of SADC". Our results are consistent with the earlier report which averaged the changes across all the SADC regions.
} 
treat the SADC FTA as a customs union in which members have a common external tariff (CET). ${ }^{25}$ First, we assume the customs union members adopt region's trade-weighted average tariff as the common external tariff. In general, this means SADC countries adopt a tariff close to South Africa's tariff, since South Africa accounts for the largest share of regional trade (see figure 2). At the other extreme, we assume the customs union members adopt the lowest tariff as the common external tariff in effect, it is impossible to enforce rules of origin. We find that all SADC countries are better off in terms of real GDP when they form a customs union with the low CET than with a SADC FTA alone (see figure12). ${ }^{26}$ The SADC countries all gain because they experience further trade liberalization with the non-member countries. Under the high CET, all countries except South Africa are better relative to the SADC FTA alone. South Africa is worse off, consistent with the observation in the data that it has lower tariffs against non-members than do the other SADC countries. It experiences an increase in tariffs under the CET constructed as average of SADC country tariffs against non-members. These sensitivity results suggest that rules of origin may not be an important issue in a SADC FTA because there is little opportunity for non-members to gain access to South Africa via the other SADC countries.

\section{SADC countries and trade relations with the EU: EBA vs. EU-SADC FTA}

In addition to participating in a SADC FTA, the poorest SADC countries - Malawi, Mozambique, Tanzania, and Zambia - have access to EU markets under the "Everything But Arms" (EBA) initiative signed in February 2001. These countries do not need to reciprocate and reduce their own trade barriers against the EU. As seen in figure 3, all four of these countries, and particularly Malawi, Mozambique and Tanzania, depend heavily on the EU as an export market. We consider two versions of EBA, first when only the EU grants unilateral access to the least developed countries and then when all OECD countries provide such access.

We find that unilateral access to the EU yields higher real GDP and real absorption gains than does the SADC FTA (see figures 5 and 6). This is not a surprise, given the importance of the EU to countries involved. Also, total exports increase further as trade becomes more liberalized. The effect on the EU is negligible. For Tanzania, Malawi and Mozambique, there are substantial gains from expanding the EBA to include all OECD countries rather than just the EU. For Zambia, the gains are small, reflecting the fact that Zambia has a larger trade share with non-OECD regions, Low-income Asia and the rest of the world.

While unilateral access to the EU helps the SADC countries eligible under the EBA, the countries benefit more from reciprocal reforms. As seen in the real GDP changes (figure 6), all other SADC countries are better off under the EU-SADC FTA than when they unilaterally have access to the EU (in addition to the FTA among SADC countries only). Reciprocal reforms lead to more structural

\footnotetext{
${ }^{25}$ Evans (2001) discusses similar problems with rules of origin for a SADC FTA. He notes that the "actual" FTA would in fact operate like a customs union with the minimum tariff as the common external tariff.

${ }^{26}$ In the sensitivity analysis of rules of origin, we continue to assume that the EU-SACU FTA is in effect, in addition to the SADC FTA.
} 
adjustment and therefore bigger gains based on comparative advantage. Note that South Africa and Botswana are slightly better off with the EU-SACU FTA \& SADC FTA \& EBA than under the EUSADC FTA. In the former configuration, those countries operate as the "hub" with the EU and the other SADC countries as a group operating like the "spokes". All SADC countries have access to the $\mathrm{EU}$ in the later experiment.

Across the three scenarios - EU-SACU FTA \& SADC FTA, EU-SACU FTA \& SADC FTA \& EBA and EU-SADC FTA - other SADC countries become more liberalized. First they allow free trade among SADC countries, then some gain access to the EU without opening their own markets to the EU, and finally they reciprocate and open markets to both SADC countries and the EU. The structural adjustment across these scenarios depends on the importance of SADC trade, EU trade and tariff rates in the region. Consider two extremes -Malawi, which is heavily dependent upon trade among SADC countries (10.3 percent of its total exports go to other SADC countries) and Tanzania, which is the least dependent on SADC trade (2.4 percent of its total exports go to other SADC countries).

In Malawi, textiles and apparel expand the most under a SADC FTA (see figure 15). This is because Malawi depends almost exclusively on the region for exports of these products, sending 90 percent of its textiles and 96 percent of its apparel exports to South Africa. It faces high tariffs from South Africa for these products - 20 percent for textiles and 23 percent for apparel so a SADC FTA in which these tariffs are removed means output expands. In most other sectors, output adjust the most with a broader FTA that includes the EU, to which Malawi initially sends 38.7 percent of its exports. The exception is processed foods in which production expands slightly more with unilateral access to the EU rather than in an EU-SADC FTA. Again the explanation can be found in the trade and tariff structure-Malawi initially sends 69 percent of its processed food exports to the EU and faces a 71 percent tariff.

In all three liberalization scenarios for Malawi, there is no absolute trade diversion (see figure 13). Instead, exports expand both to FTA and non-FTA members. When in a SADC FTA, there is only relative trade diversion as exports to FTA members expands more than exports to non-FTA members. However, when Malawi enjoys unilateral access to the EU in addition to the SADC FTA, its exports to non-SADC members expands more than exports to SADC FTA partners because it sells more to the EU. Trade expands the most under an EU-SADC FTA.

In Tanzania, a SADC FTA yields small changes in production, because Tanzania does not depend on the region for trade (see figure 16). However, an FTA with the EU introduces more structural adjustment. In general, there is more adjustment with an EU-SADC FTA than with unilateral access to the EU. The big gainers for Tanzania, under an EU-SADC FTA, are textiles, fruits \& vegetables and other agriculture. In both Tanzania and Malawi, the structural change is consistent with comparative advantage as a developing country liberalizes with a developed trade partner: capital intensive goods such as capital goods and intermediates contract while labor intensive goods such as textiles expand. Tanzania does experience some absolute trade diversion in a SADC FTA and an EUSADC FTA (see figure 14). This is due to its low initial trade with SADC and the EU - some of the 
increase in exports to these regions comes at the expense of exports to other regions.

\section{Conclusions}

We have developed a multi-country model that focuses on Southern Africa to analyze the impact on African economies of existing regional trade initiatives and expansions of those initiatives. The model is used as a simulation laboratory to sort out the relative empirical importance of different types of trade liberalization. The empirical results lead to a number of conclusions:

- $\quad$ Trade creation dominates trade diversion for the region under all FTA arrangements.

- $\quad$ Some SADC economies are slightly hurt by the FTA between EU and SACU while some benefit slightly. Overall, the agreement is not a beggar thy neighbor policy.

- $\quad$ A SADC FTA in conjunction with the EU-SACU FTA improves welfare for all SADC countries.

- $\quad$ An FTA with the EU and all SADC countries dominates other regional agreements for the SADC countries except South Africa and Botswana (who are slightly worse off because they are no longer the "hub" in a "hub and spoke" FTA).

- $\quad$ The EBA initiative yields higher real GDP and real absorption gains than a SADC FTA.

- $\quad$ Reciprocal reforms under an EU-SADC FTA dominate unilateral access to the EU under the EBA initiative because they lead to more structural adjustment.

- $\quad$ The South African economy is not large enough to serve as a growth pole for the region. Access to EU markets provides substantially bigger gains for the other SADC countries than access to South Africa. 


\section{References}

Andrianmananjara, Soamiely and Russell Hillberry (2001). "Regionalism, Trade and Growth: The Case of the EU-South Africa Free Trade Agreement." U.S. International Trade Commission, Office of Economics, Working Paper no. 2001-07-A, July.

Alston, Julian M., Colin A. Carter, Richard Green, and Daniel Pick (1989). "Whither Armington Trade Models?" American Journal of Agricultural Economics. Vol. 72, no. 2, pp. 455-67.

Armington, Paul (1969). "A Theory of Demand for Products Distinguished by Place of Production." IMF Staff Papers. Vol. 16, no. 1, pp. 159-178.

Baldwin, Richard E. and Anthony J. Venables (1995). "Regional Economic Integration.” In G. Grossman and K. Rogoff, eds. Handbook of International Economics, Vol. III. Amsterdam: Elsevier.

Bjornskov, Christian and Ekaterina Krivonos (2001). "From Lome to Cotonou, The New EU-ACP Agreement.” Unpublished manuscript, Danish Institute of Agriculture and Fisheries Economics.

Brown, Drusilla (1987). "Tariffs, the Terms of Trade, and Natural Product Differentiation." Journal of Policy Modeling. Vol. 9, pp. 503-26.

Crawford, Jo-Ann and Sam Laird (2001). "Regional Trade Agreements and the WTO." North American Journal of Economics and Finance, Vol. 12, pp. 193-211.

Davies, Robert (1998). “The Resource Allocation Effects of European Union-South Africa Free Trade Agreements: A General Equilibrium Analysis Using GTAP.” Paper prepared for Trade and Industrial Policy Secretariat 1998 Annual Forem, Muldersdrift.

Devarajan, Shantayanan, Jeffrey D. Lewis and Sherman Robinson (1990). "Policy Lessons from Trade-Focused, Two-Sector Models.” Journal of Policy Modeling. Vol. 12, pp. 625-657.

Devarajan, Shantayanan, Jeffrey D. Lewis and Sherman Robinson (1993). "External Shocks, Purchasing Power Parity, and the Equilibrium Real Exchange Rate." World Bank Economic Review, Vol. 7, no. 1 (January), pp. 45-63.

Evans, David (2001). "Options for Regional Integration in Southern Africa." The South African Journal of Economics, Vol 64, no 4, pp. 662-92.

Goldin, Ian, Odin Knudsen, and Dominique van der Mensbrugghe (1993). Trade Liberalisation: Global Economic Implications. Paris: OECD. 
Hanson, Kenneth, Sherman Robinson, and Stephen Tokarick (1993). "U.S. Adjustment in the 1990s: A CGE Analysis of Alternative Trade Strategies." International Economics Journal, Vol. 7, no. 2 , pp. $27-49$.

Hertel, Thomas, ed. (1997). Global Trade Analysis: Modeling and Applications. Cambridge: Cambridge University Press.

Hertel, Thomas W., William A. Masters, and Aziz Elbehri (1998). "The Uruguay Round and Africa: a Global, General Equilibrium Analysis," Journal of African Economies, Vol. 7, no 2, pp. 203 234.

Hinojosa-Ojeda, Raúl, Jeffrey D. Lewis, and Sherman Robinson (1995). "Regional Integration Options for Central America and the Caribbean After NAFTA." The North American Journal of Economics and Finance. Vol. 6, no. 2, pp. 121-48.

Lewis, Jeffrey D. (2001). "Reform and Opportunity: The Changing Role and Patterns of Trade in South Africa and SADC," Africa Region Working Paper Series No.14, The World Bank, Washington DC.

Lewis, Jeffrey D., Sherman Robinson, and Zhi Wang (1995). "Beyond the Uruguay Round: The Implications of an Asian Free Trade Area." China Economic Review. Vol. 6, no.1, pp. 3590.

Lewis, Jeffrey D. and Sherman Robinson (1996). "Partners or Predators? The Impact of Regional Trade Liberalization on Indonesia.” Policy Research Working Paper 1626, Washington D.C.: The World Bank.

Lewis, Jeffrey D., Sherman Robinson, and Karen Thierfelder (1999). "After the Negotiations: Assessing the Impact of Regional Trade Agreements in Southern Africa." International Food Policy Research Institute, Trade and Macroeconomics Division Working Paper No. 46, Washington D.C.

McDonald, Scott and Terrie Walmsley (2001). "Bilateral Free Trade Agreements and Customs Unions: The Impact of the EU South Africa Free Trade Agreement on Botswana." Paper prepared for the $4^{\text {th }}$ Global Economic Analysis Conference, Global Trade Analysis Project, Purdue University, June.

de Melo, Jaime and Sherman Robinson (1989). "Product Differentiation and the Treatment of Foreign Trade in Computable General Equilibrium Models of Small Economies." Journal of International Economics. Vol. 27, no. 1-2 (August), pp. 47-67.

OECD (1990). "Special Issue: Modelling the Effects of Agricultural Policies." OECD Economic Studies. No. 13 (Winter, 1989-90). 
Panagariya, Arvind (2000). "Preferential Trade Liberalization: The Traditional Theory and New Developments." Journal of Economic Literature, Vol. XXXVIII (June) pp. 287-331.

Pyatt, Graham and Jeffery I. Round, eds. (1985). Social Accounting Matrices: A Basis for Planning. Washington, DC: The World Bank

Robinson, Sherman (1989). "Multisectoral Models." In H.B. Chenery and T.N. Srinivasan, eds. Handbook of Development Economics. Amsterdam: North-Holland.

Robinson, Sherman, Mary E. Burfisher, Raul Hinojosa-Ojeda, and Karen Thierfelder (1993). "Agricultural Policies and Migration in a U.S.-Mexico Free Trade Area." Journal of Policy Modeling, Vol. 15, nos. 5\&6, pp. 673-701.

Robinson, Sherman and Karen Thierfelder (1999). "Trade Liberalization and Regional Integration: The Search for Large Numbers." International Food Policy Research Institute, Trade and Macroeconomics Division Working Paper No. 34, Washington D.C.

Shoven, John B. and John Whalley (1984). "Applied General-Equilibrium Models of Taxation and International Trade." Journal of Economic Literature. Vol. 22, no. 3 (September), pp. 1007-1051.

Tsikata, Yvonne M (1999). "Southern Africa: Trade, Liberalization and Implications for a Free Trade Area." Processed (September).

Whalley, John (1985). Trade Liberalization Among Major World Trading Areas. Cambridge, MA: MIT Press.

Winters, L. Alan (1996). Regionalism versus Multilateralism. Policy Research Working Paper 1687, World Bank, Washington. 
Tables and Figures

Figure 1a: SADC GDP

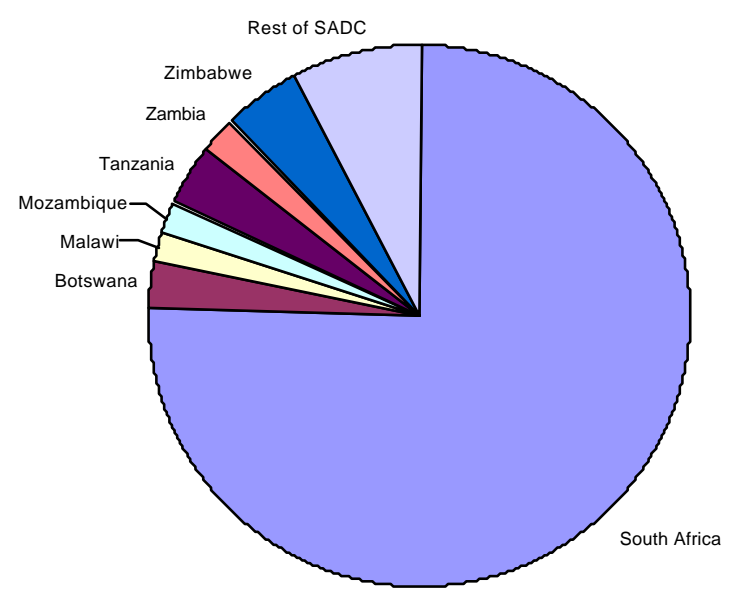

Figure 1b: SADC Exports

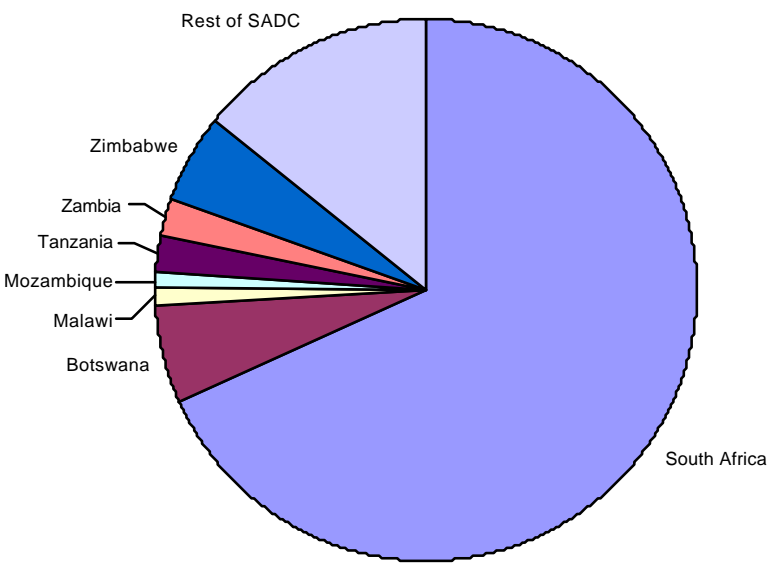


Figure 2a: EU and African GDP

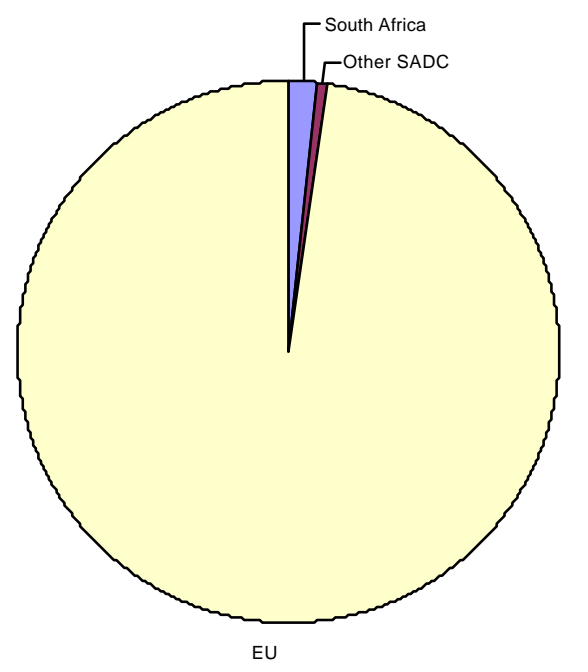

Figure 2b: EU and African Exports

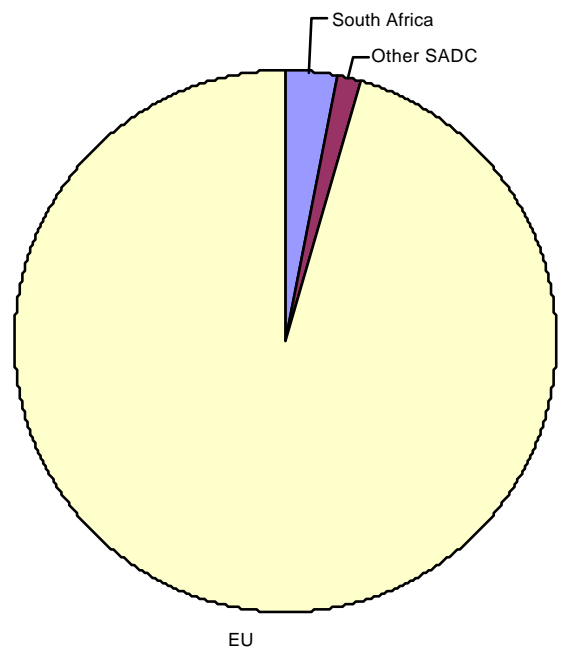




\begin{tabular}{|c|c|c|c|c|c|c|c|c|c|}
\hline & $\begin{array}{l}\text { South } \\
\text { Africa }\end{array}$ & Botswana & Malawi & Mozambique & Tanzania & Zambia & Zimbabwe & $\begin{array}{l}\text { Rest of } \\
\text { SADC }\end{array}$ & EU \\
\hline \multicolumn{10}{|c|}{ GDP \& Trade Flows (billions US\$) } \\
\hline GDP & 139.080 & 5.025 & 2.809 & 3.610 & 6.658 & 4.196 & 8.224 & 14.148 & 8187.225 \\
\hline Exports & 35.013 & 2.911 & 0.636 & 0.427 & 1.135 & 1.116 & 2.613 & 7.310 & 1125.603 \\
\hline Imports & 31.230 & 2.125 & 0.523 & 0.938 & 2.087 & 0.957 & 3.152 & 4.786 & 959.639 \\
\hline \multicolumn{10}{|l|}{ Trade Dependence (percent) } \\
\hline Exports/GDP & 0.252 & 0.579 & 0.227 & 0.118 & 0.171 & 0.266 & 0.318 & 0.517 & 0.137 \\
\hline Imports/GDP & 0.225 & 0.423 & 0.186 & 0.260 & 0.314 & 0.228 & 0.383 & 0.338 & 0.117 \\
\hline \multicolumn{10}{|c|}{ Factor Share in Value Added (percent) } \\
\hline Land & 0.005 & 0.004 & 0.039 & 0.044 & 0.056 & 0.030 & 0.019 & 0.011 & 0.003 \\
\hline Unskilled Labor & 0.406 & 0.227 & 0.431 & 0.422 & 0.433 & 0.397 & 0.385 & 0.275 & 0.334 \\
\hline Skilled Labor & 0.195 & 0.122 & 0.095 & 0.081 & 0.054 & 0.103 & 0.149 & 0.113 & 0.222 \\
\hline Capital & 0.372 & 0.612 & 0.426 & 0.442 & 0.445 & 0.457 & 0.438 & 0.502 & 0.438 \\
\hline Natural Resources & 0.022 & 0.034 & 0.009 & 0.009 & 0.012 & 0.013 & 0.008 & 0.099 & 0.003 \\
\hline Share of labor in agriculture & 0.025 & 0.030 & 0.331 & 0.429 & 0.545 & 0.285 & 0.145 & 0.129 & 0.030 \\
\hline Unskilled share of labor force & 0.674 & 0.649 & 0.819 & 0.837 & 0.888 & 0.793 & 0.718 & 0.714 & 0.600 \\
\hline
\end{tabular}




\begin{tabular}{|c|c|c|c|c|c|c|c|c|c|}
\hline & $\begin{array}{l}\text { South } \\
\text { Africa }\end{array}$ & Botswana & Malawi & Mozambique & Tanzania & Zambia & Zimbabwe & $\begin{array}{l}\text { Rest of } \\
\text { SADC }\end{array}$ & EU \\
\hline \multicolumn{10}{|c|}{ share of total output value } \\
\hline Grain & 0.6 & 0.5 & 7.4 & 5.0 & 9.5 & 3.9 & 1.8 & 1.3 & 30.4 \\
\hline Fruits \& Vegetables & 0.7 & 0.2 & 2.4 & 5.9 & 6.8 & 1.4 & 1.4 & 1.7 & 0.4 \\
\hline Other Agriculture & 0.4 & 0.0 & 15.8 & 6.6 & 8.4 & 4.9 & 7.8 & 2.1 & 0.3 \\
\hline Livestock & 1.9 & 1.6 & 1.4 & 2.3 & 2.1 & 2.0 & 3.1 & 1.6 & 1.2 \\
\hline Forestry \& Fisheries & 0.6 & 0.1 & 2.2 & 4.1 & 3.9 & 4.4 & 0.3 & 0.8 & 0.4 \\
\hline Energy \& Mines & 5.3 & 28.1 & 0.6 & 0.2 & 1.3 & 1.3 & 4.0 & 20.9 & 0.4 \\
\hline Food Processing & 6.8 & 5.1 & 10.9 & 10.8 & 15.7 & 11.2 & 11.9 & 7.6 & 5.4 \\
\hline Textiles & 1.6 & 0.4 & 1.4 & 0.5 & 0.4 & 1.7 & 3.5 & 3.7 & 0.9 \\
\hline Apparel & 0.6 & 0.5 & 1.6 & 0.4 & 2.0 & 1.4 & 0.7 & 2.3 & 1.1 \\
\hline Wood \& Paper & 3.6 & 0.7 & 3.3 & 0.7 & 1.4 & 2.2 & 1.9 & 1.2 & 3.2 \\
\hline Basic Intermediates & 13.9 & 1.9 & 6.5 & 1.7 & 4.9 & 12.1 & 10.2 & 6.2 & 9.4 \\
\hline Machinery \& Equipment & 9.2 & 6.8 & 3.1 & 0.7 & 1.6 & 3.3 & 5.6 & 4.7 & 14.8 \\
\hline Utilities & 5.6 & 1.6 & 1.4 & 1.7 & 1.7 & 7.0 & 3.6 & 1.0 & 1.6 \\
\hline Construction & 4.6 & 12.0 & 1.5 & 9.1 & 4.2 & 5.5 & 7.6 & 7.0 & 6.9 \\
\hline Trade & 18.7 & 12.1 & 25.2 & 32.4 & 20.5 & 19.3 & 15.4 & 15.8 & 16.5 \\
\hline Private Service & 13.5 & 10.8 & 12.0 & 12.7 & 9.3 & 12.8 & 9.9 & 10.1 & 24.9 \\
\hline Public Service & 12.6 & 17.3 & 3.3 & 5.1 & 6.2 & 5.9 & 11.2 & 12.0 & 12.2 \\
\hline
\end{tabular}




\begin{tabular}{|c|c|c|c|c|c|c|c|c|c|}
\hline & $\begin{array}{l}\text { South } \\
\text { Africa }\end{array}$ & Botswana & Malawi & Mozambique & Tanzania & Zambia & Zimbabwe & $\begin{array}{l}\text { Rest of } \\
\text { SADC }\end{array}$ & EU \\
\hline \multicolumn{10}{|c|}{ share of total exports valued at world market prices } \\
\hline Grain & 0.8 & 0.0 & 0.8 & 2.1 & 2.2 & 0.4 & 3.4 & 0.1 & 0.2 \\
\hline Fruits \& Vegetables & 2.0 & 0.0 & 0.6 & 6.6 & 7.3 & 0.6 & 1.5 & 0.1 & 0.2 \\
\hline Other Agriculture & 0.5 & 0.0 & 67.4 & 6.5 & 32.5 & 3.7 & 32.9 & 0.2 & 0.2 \\
\hline Livestock & 0.5 & 0.2 & 0.0 & 0.1 & 1.3 & 0.1 & 0.4 & 0.1 & 0.2 \\
\hline Forestry \& Fisheries & 0.4 & 0.0 & 0.1 & 2.9 & 2.6 & 0.4 & 0.3 & 0.1 & 0.1 \\
\hline Energy \& Mines & 12.3 & 74.8 & 2.3 & 2.0 & 0.1 & 1.6 & 3.9 & 59.5 & 0.5 \\
\hline Food Processing & 4.0 & 2.2 & 3.4 & 25.7 & 10.9 & 2.6 & 7.4 & 6.6 & 4.2 \\
\hline Textiles & 1.7 & 1.0 & 4.0 & 2.1 & 1.5 & 3.4 & 2.7 & 5.0 & 2.2 \\
\hline Apparel & 1.5 & 1.2 & 3.7 & 0.8 & 2.8 & 0.2 & 2.2 & 6.5 & 2.1 \\
\hline Wood \& Paper & 4.2 & 0.3 & 0.3 & 0.8 & 0.7 & 0.2 & 3.9 & 0.2 & 3.0 \\
\hline Basic Intermediates & 40.3 & 1.7 & 0.5 & 3.1 & 3.1 & 57.1 & 20.0 & 0.9 & 16.9 \\
\hline Machinery \& Equipment & 15.7 & 10.6 & 0.6 & 6.2 & 4.1 & 3.4 & 7.2 & 6.4 & 38.2 \\
\hline Utilities & 1.1 & 0.1 & 0.1 & 8.2 & 0.0 & 9.7 & 0.0 & 0.1 & 0.4 \\
\hline Construction & 0.0 & 0.2 & 0.5 & 1.1 & 0.9 & 0.5 & 0.4 & 0.1 & 0.8 \\
\hline Trade & 9.8 & 3.7 & 8.2 & 17.4 & 22.0 & 9.1 & 7.3 & 8.3 & 17.2 \\
\hline Private Service & 3.7 & 3.2 & 6.5 & 12.7 & 6.4 & 6.1 & 5.1 & 4.8 & 11.6 \\
\hline Public Service & 1.3 & 0.8 & 0.8 & 1.8 & 1.7 & 0.9 & 1.3 & 1.1 & 1.8 \\
\hline
\end{tabular}




\begin{tabular}{|c|c|c|c|c|c|c|c|c|c|}
\hline & $\begin{array}{l}\text { South } \\
\text { Africa }\end{array}$ & Botswana & Malawi & Mozambique & Tanzania & Zambia & Zimbabwe & Rest of SADC & EU \\
\hline \multicolumn{10}{|c|}{ share of total imports valued at world market prices } \\
\hline Grain & 0.5 & 1.9 & 0.3 & 3.9 & 1.3 & 0.9 & 1.6 & 0.9 & 0.7 \\
\hline Fruits \& Vegetables & 0.2 & 0.9 & 0.0 & 0.2 & 0.3 & 0.0 & 0.2 & 1.0 & 0.8 \\
\hline Other Agriculture & 0.5 & 0.5 & 0.7 & 0.4 & 0.2 & 0.2 & 1.2 & 0.5 & 1.5 \\
\hline Livestock & 0.2 & 0.3 & 0.0 & 0.0 & 0.1 & 0.1 & 0.2 & 0.5 & 0.4 \\
\hline Forestry \& Fisheries & 0.1 & 0.3 & 0.0 & 0.0 & 0.0 & 0.0 & 0.0 & 0.1 & 0.4 \\
\hline Energy \& Mines & 5.4 & 1.7 & 1.9 & 0.5 & 4.0 & 8.3 & 1.8 & 0.5 & 10.3 \\
\hline Food Processing & 4.1 & 9.5 & 1.5 & 5.5 & 9.3 & 1.1 & 2.3 & 12.6 & 3.0 \\
\hline Textiles & 3.1 & 3.0 & 3.8 & 4.5 & 3.0 & 3.2 & 4.2 & 9.1 & 2.7 \\
\hline Apparel & 2.2 & 3.3 & 0.9 & 5.1 & 2.2 & 1.5 & 0.7 & 2.1 & 4.9 \\
\hline Wood \& Paper & 3.0 & 6.5 & 4.9 & 3.3 & 2.3 & 4.3 & 2.7 & 3.6 & 2.8 \\
\hline Basic Intermediates & 17.5 & 21.1 & 28.5 & 28.1 & 14.3 & 21.4 & 28.6 & 12.7 & 12.0 \\
\hline Machinery \& Equipment & 47.8 & 39.7 & 39.7 & 32.1 & 35.0 & 41.6 & 39.5 & 38.9 & 31.5 \\
\hline Utilities & 0.0 & 0.4 & 0.7 & 3.8 & 0.2 & 0.0 & 6.5 & 0.1 & 0.4 \\
\hline Construction & 0.1 & 0.3 & 0.7 & 0.5 & 0.3 & 0.6 & 0.4 & 0.2 & 1.1 \\
\hline Trade & 8.6 & 4.9 & 7.0 & 4.9 & 13.3 & 7.7 & 4.7 & 7.3 & 14.1 \\
\hline Private Service & 5.5 & 4.7 & 8.0 & 6.1 & 10.9 & 7.4 & 4.5 & 8.7 & 11.1 \\
\hline Public Service & 1.5 & 0.9 & 1.5 & 1.1 & 3.3 & 1.6 & 0.9 & 1.1 & 2.4 \\
\hline
\end{tabular}




\begin{tabular}{|c|c|c|c|c|c|c|c|c|c|}
\hline \multicolumn{10}{|l|}{ South Africa } \\
\hline & $\begin{array}{l}\text { South } \\
\text { Africa }\end{array}$ & Botswana & Malawi & Mozambique & Tanzania & Zambia & Zimbabwe & $\begin{array}{l}\text { Rest of } \\
\text { SADC }\end{array}$ & EU \\
\hline Grain & 0.0 & 0.0 & 0.0 & 0.0 & 37.5 & 0.0 & 37.3 & 33.3 & 38.8 \\
\hline Fruits \& Vegetables & 0.0 & 0.0 & 0.0 & 0.0 & 20.0 & 0.0 & 25.7 & 0.0 & 25.5 \\
\hline Other Agriculture & 0.0 & 0.0 & 0.0 & 0.0 & 13.4 & 0.0 & 12.9 & 0.0 & 9.3 \\
\hline Livestock & 0.0 & 0.0 & 0.0 & 0.0 & 7.7 & 0.0 & 7.2 & 0.0 & 7.3 \\
\hline Forestry \& Fisheries & 0.0 & 0.0 & 0.0 & 0.0 & 0.0 & 0.0 & 0.0 & 0.0 & 0.3 \\
\hline Energy \& Mines & 0.0 & 0.0 & 0.0 & 0.0 & 0.0 & 0.0 & 7.5 & 0.0 & 0.1 \\
\hline Food Processing & 0.0 & 0.0 & 100.0 & 0.0 & 48.7 & 50.0 & 65.3 & 71.4 & 71.4 \\
\hline Textiles & 0.0 & 0.0 & 20.2 & 19.3 & 16.7 & 10.0 & 13.5 & 9.6 & 14.3 \\
\hline Apparel & 0.0 & 0.0 & 23.3 & 13.4 & 25.0 & 0.0 & 28.0 & 30.6 & 26.2 \\
\hline Wood \& Paper & 0.0 & 0.0 & 10.5 & 0.0 & 33.3 & 10.0 & 10.8 & 8.3 & 8.3 \\
\hline Basic Intermediates & 0.0 & 0.0 & 0.0 & 31.5 & 0.0 & 0.2 & 4.1 & 3.5 & 5.7 \\
\hline Machinery \& Equipment & 0.0 & 0.0 & 8.6 & 1.8 & 3.9 & 8.4 & 8.7 & 7.1 & 7.5 \\
\hline Total & 0.0 & 0.0 & 21.0 & 9.5 & 19.8 & 3.4 & 18.9 & 4.8 & 8.0 \\
\hline \multicolumn{10}{|l|}{ Botswana } \\
\hline & $\begin{array}{l}\text { South } \\
\text { Africa }\end{array}$ & Botswana & Malawi & Mozambique & Tanzania & Zambia & Zimbabwe & $\begin{array}{l}\text { Rest of } \\
\text { SADC }\end{array}$ & $\mathrm{EU}$ \\
\hline Grain & 0.0 & 0.0 & 0.0 & 0.0 & 0.0 & 37 & 40.7 & 0.0 & 0.0 \\
\hline Fruits \& Vegetables & 0.0 & 0.0 & 0.0 & 0.0 & 0.0 & 0.0 & 0.0 & 0.0 & 50.0 \\
\hline Other Agriculture & 0.0 & 0.0 & 8.6 & 0.0 & 0.0 & 34.1 & 9.3 & 0.0 & 0.0 \\
\hline Livestock & 0.0 & 0.0 & 0.0 & 0.0 & 0.0 & 0.0 & 0.0 & 0.0 & 0.0 \\
\hline Forestry \& Fisheries & 0.0 & 0.0 & 0.0 & 0.0 & 22.2 & 44.4 & 43.4 & 0.0 & 50.0 \\
\hline Energy \& Mines & 0.0 & 0.0 & 0.0 & 0.0 & 0.0 & 0.0 & 0.0 & 7.7 & 28.7 \\
\hline Food Processing & 0.0 & 0.0 & 0.0 & 0.0 & 0.0 & 0.0 & 69.8 & 0.0 & 67.2 \\
\hline Textiles & 0.0 & 0.0 & 25.9 & 0.0 & 0.0 & 25.0 & 25.2 & 25.9 & 25.1 \\
\hline Apparel & 0.0 & 0.0 & 0.0 & 0.0 & 0.0 & 0.0 & 21.8 & 0.0 & 21.1 \\
\hline Wood \& Paper & 0.0 & 0.0 & 0.0 & 0.0 & 0.0 & 27.8 & 27.2 & 0.0 & 26.5 \\
\hline Basic Intermediates & 0.0 & 0.0 & 0.0 & 0.0 & 0.0 & 27.6 & 25.8 & 0.0 & 24.9 \\
\hline Machinery \& Equipment & 0.0 & 0.0 & 0.0 & 0.0 & 0.0 & 22.2 & 44.1 & 22.2 & 23.2 \\
\hline Total & 0.0 & 0.0 & 12.0 & 0.0 & 19.3 & 29.5 & 42.7 & 16.6 & 18.6 \\
\hline \multicolumn{10}{|l|}{ Malawi } \\
\hline & $\begin{array}{l}\text { South } \\
\text { Africa }\end{array}$ & Botswana & Malawi & Mozambique & Tanzania & Zambia & Zimbabwe & $\begin{array}{l}\text { Rest of } \\
\text { SADC }\end{array}$ & EU \\
\hline Grain & 0.0 & 0.0 & 0.0 & 0.0 & 0.0 & 0.0 & 0.0 & 0.0 & 0.0 \\
\hline Fruits \& Vegetables & 0.0 & 0.0 & 0.0 & 0.0 & 0.0 & 0.0 & 0.0 & 0.0 & 0.0 \\
\hline Other Agriculture & 0.0 & 0.0 & 0.0 & 0.0 & 0.0 & 0.0 & 35.4 & 0.0 & 100.0 \\
\hline Livestock & 0.0 & 0.0 & 0.0 & 0.0 & 0.0 & 0.0 & 0.0 & 0.0 & 12.5 \\
\hline Forestry \& Fisheries & 0.0 & 0.0 & 0.0 & 0.0 & 0.0 & 0.0 & 0.0 & 0.0 & 0.0 \\
\hline Energy \& Mines & 0.0 & 0.0 & 0.0 & 0.0 & 0.0 & 0.0 & 0.0 & 0.0 & 0.0 \\
\hline Food Processing & 0.0 & 0.0 & 0.0 & 0.0 & 0.0 & 0.0 & 20.3 & 0.0 & 32.0 \\
\hline Textiles & 36.0 & 0.0 & 0.0 & 0.0 & 0.0 & 0.0 & 39.0 & 0.0 & 35.0 \\
\hline Apparel & 41.3 & 0.0 & 0.0 & 0.0 & 0.0 & 0.0 & 41.8 & 0.0 & 33.9 \\
\hline Wood \& Paper & 20.0 & 0.0 & 0.0 & 0.0 & 0.0 & 0.0 & 22.9 & 0.0 & 22.8 \\
\hline Basic Intermediates & 13.5 & 12.3 & 0.0 & 0.0 & 0.0 & 0.0 & 10.9 & 0.0 & 9.8 \\
\hline Machinery \& Equipment & 20.2 & 7.4 & 0.0 & 0.0 & 17.6 & 0.0 & 23.5 & 16.7 & 22.7 \\
\hline Total & 18.3 & 8.0 & 0.0 & 0.0 & 15.0 & 0.0 & 18.0 & 4.8 & 14.7 \\
\hline
\end{tabular}


Source: Southern African Model data base derived from GTAP 5.0, final version.

\begin{tabular}{|c|c|c|c|c|c|c|c|c|c|}
\hline \multicolumn{10}{|c|}{ Table 5 (continued): Sectoral Bilateral Tariffs and Non-Tariff Barriers (percent ad valorem) } \\
\hline \multicolumn{10}{|l|}{ Mozambique } \\
\hline & $\begin{array}{l}\text { South } \\
\text { Africa }\end{array}$ & Botswana & Malawi & Mozambique & Tanzania & Zambia & Zimbabwe & $\begin{array}{l}\text { Rest of } \\
\text { SADC }\end{array}$ & $\mathrm{EU}$ \\
\hline Grain & 0.0 & 0.0 & 0.0 & 0.0 & 0.0 & 0.0 & 1.2 & 0.0 & 2.4 \\
\hline Fruits \& Vegetables & 0.0 & 0.0 & 0.0 & 0.0 & 0.0 & 0.0 & 8.7 & 0.0 & 25.0 \\
\hline Other Agriculture & 0.0 & 0.0 & 0.0 & 0.0 & 0.0 & 0.0 & 11.2 & 0.0 & 4.1 \\
\hline Livestock & 0.0 & 0.0 & 0.0 & 0.0 & 0.0 & 0.0 & 0.0 & 0.0 & 0.0 \\
\hline Forestry \& Fisheries & 0.0 & 0.0 & 0.0 & 0.0 & 0.0 & 0.0 & 0.0 & 0.0 & 0.0 \\
\hline Energy \& Mines & 4.1 & 0.0 & 0.0 & 0.0 & 0.0 & 0.0 & 0.0 & 0.0 & 0.0 \\
\hline Food Processing & 0.0 & 0.0 & 0.0 & 0.0 & 50.0 & 0.0 & 5.1 & 0.0 & 32.2 \\
\hline Textiles & 31.2 & 0.0 & 0.0 & 0.0 & 0.0 & 0.0 & 16.9 & 0.0 & 19.3 \\
\hline Apparel & 35.0 & 17.0 & 0.0 & 0.0 & 0.0 & 0.0 & 11.1 & 0.0 & 32.6 \\
\hline Wood \& Paper & 19.1 & 0.0 & 0.0 & 0.0 & 0.0 & 0.0 & 12.5 & 0.0 & 20.2 \\
\hline Basic Intermediates & 12.7 & 0.0 & 0.0 & 0.0 & 0.0 & 0.0 & 7.9 & 0.0 & 8.9 \\
\hline Machinery \& Equipment & 12.1 & 9.3 & 0.0 & 0.0 & 0.0 & 0.0 & 9.7 & 0.0 & 10.5 \\
\hline Total & 16.0 & 15.6 & 0.0 & 0.0 & 24.8 & 0.0 & 6.8 & 0.0 & 9.5 \\
\hline \multicolumn{10}{|l|}{ Tanzania } \\
\hline & $\begin{array}{l}\text { South } \\
\text { Africa }\end{array}$ & Botswana & Malawi & Mozambique & Tanzania & Zambia & Zimbabwe & $\begin{array}{l}\text { Rest of } \\
\text { SADC }\end{array}$ & EU \\
\hline Grain & 17.9 & 0.0 & 16.7 & 29.5 & 0.0 & 0.0 & 0.0 & 0.0 & 17.6 \\
\hline Fruits \& Vegetables & 50.0 & 0.0 & 21.4 & 0.0 & 0.0 & 0.0 & 0.0 & 0.0 & 8.0 \\
\hline Other Agriculture & 25.0 & 0.0 & 0.0 & 0.0 & 0.0 & 0.0 & 39.1 & 0.0 & 30.0 \\
\hline Livestock & 0.0 & 0.0 & 0.0 & 27.3 & 0.0 & 0.0 & 18.2 & 0.0 & 28.1 \\
\hline Forestry \& Fisheries & 50.0 & 0.0 & 0.0 & 0.0 & 0.0 & 0.0 & 0.0 & 0.0 & 10.3 \\
\hline Energy \& Mines & 13.0 & 5.6 & 0.0 & 0.0 & 0.0 & 0.0 & 0.0 & 4.3 & 2.1 \\
\hline Food Processing & 28.1 & 0.0 & 27.8 & 27.8 & 0.0 & 33.3 & 30.2 & 33.3 & 22.2 \\
\hline Textiles & 17.8 & 0.0 & 0.0 & 0.0 & 0.0 & 31.3 & 21.1 & 0.0 & 15.4 \\
\hline Apparel & 15.8 & 0.0 & 0.0 & 0.0 & 0.0 & 0.0 & 0.0 & 0.0 & 18.7 \\
\hline Wood \& Paper & 32.9 & 0.0 & 33.3 & 0.0 & 0.0 & 30.6 & 29.1 & 33.3 & 27.5 \\
\hline Basic Intermediates & 17.7 & 1.9 & 8.7 & 0.0 & 0.0 & 14.0 & 25.8 & 6.1 & 16.8 \\
\hline Machinery \& Equipment & 17.6 & 0.0 & 17.2 & 5.3 & 0.0 & 20.7 & 15.6 & 8.8 & 17.0 \\
\hline Total & 19.9 & 2.7 & 17.0 & 11.0 & 0.0 & 18.3 & 24.7 & 4.8 & 11.8 \\
\hline \multicolumn{10}{|l|}{ Zambia } \\
\hline & $\begin{array}{l}\text { South } \\
\text { Africa }\end{array}$ & Botswana & Malawi & Mozambique & Tanzania & Zambia & Zimbabwe & $\begin{array}{l}\text { Rest of } \\
\text { SADC }\end{array}$ & $\mathrm{EU}$ \\
\hline Grain & 0.0 & 0.0 & 0.0 & 0.0 & 0.0 & 0.0 & 3.1 & 0.0 & 0.0 \\
\hline Fruits \& Vegetables & 0.0 & 0.0 & 0.0 & 0.0 & 0.0 & 0.0 & 25.0 & 0.0 & 13.0 \\
\hline Other Agriculture & 0.0 & 0.0 & 0.0 & 0.0 & 0.0 & 0.0 & 8.5 & 0.0 & 5.0 \\
\hline Livestock & 0.0 & 0.0 & 0.0 & 0.0 & 0.0 & 0.0 & 0.0 & 0.0 & 8.4 \\
\hline Forestry \& Fisheries & 0.0 & 0.0 & 0.0 & 0.0 & 0.0 & 0.0 & 0.0 & 0.0 & 0.0 \\
\hline Energy \& Mines & 6.3 & 21.2 & 22.2 & 0.0 & 0.0 & 0.0 & 20.5 & 20.4 & 20.1 \\
\hline Food Processing & 0.0 & 11.1 & 0.0 & 0.0 & 25.0 & 0.0 & 10.9 & 0.0 & 16.5 \\
\hline Textiles & 15.3 & 0.0 & 0.0 & 0.0 & 28.6 & 0.0 & 25.0 & 0.0 & 12.0 \\
\hline Apparel & 24.9 & 0.0 & 0.0 & 0.0 & 0.0 & 0.0 & 23.5 & 33.3 & 24.4 \\
\hline Wood \& Paper & 19.1 & 7.4 & 0.0 & 0.0 & 25.0 & 0.0 & 7.2 & 0.0 & 10.0 \\
\hline Basic Intermediates & 10.6 & 3.7 & 0.0 & 0.0 & 0.0 & 0.0 & 4.0 & 16.7 & 10.3 \\
\hline Machinery \& Equipment & 12.9 & 18.5 & 0.0 & 0.0 & 0.0 & 0.0 & 15.0 & 6.7 & 10.9 \\
\hline Total & 12.7 & 13.9 & 20.2 & 0.0 & 20.0 & 0.0 & 6.4 & 17.8 & 11.0 \\
\hline
\end{tabular}




\begin{tabular}{|c|c|c|c|c|c|c|c|c|c|}
\hline \multicolumn{10}{|c|}{ Table 5 (continued): Sectoral Bilateral Tariffs and Non-Tariff Barriers (percent ad valorem) } \\
\hline \multicolumn{10}{|l|}{ Zimbabwe } \\
\hline & $\begin{array}{l}\text { South } \\
\text { Africa }\end{array}$ & Botswana & Malawi & Mozambique & Tanzania & Zambia & Zimbabwe & $\begin{array}{l}\text { Rest of } \\
\text { SADC }\end{array}$ & EU \\
\hline Grain & 7.4 & 0.0 & 0.3 & 0.0 & 0.0 & 0.9 & 0.0 & 0.0 & 6.3 \\
\hline Fruits \& Vegetables & 35.0 & 0.0 & 25.0 & 33.3 & 0.0 & 0.0 & 0.0 & 0.0 & 14.3 \\
\hline Other Agriculture & 55.1 & 0.0 & 11.9 & 18.8 & 95.5 & 11.8 & 0.0 & 0.0 & 8.0 \\
\hline Livestock & 13.7 & 0.0 & 0.0 & 0.0 & 0.0 & 0.0 & 0.0 & 0.0 & 4.2 \\
\hline Forestry \& Fisheries & 10.8 & 0.0 & 0.0 & 0.0 & 0.0 & 0.0 & 0.0 & 0.0 & 0.0 \\
\hline Energy \& Mines & 5.9 & 27.2 & 0.0 & 27.5 & 0.0 & 0.0 & 0.0 & 0.0 & 7.0 \\
\hline Food Processing & 30.4 & 24.3 & 24.5 & 24.3 & 50.0 & 24.1 & 0.0 & 27.6 & 43.0 \\
\hline Textiles & 28.4 & 28.1 & 27.3 & 27.6 & 30.0 & 28.6 & 0.0 & 38.6 & 19.4 \\
\hline Apparel & 80.4 & 33.3 & 30.8 & 33.3 & 0.0 & 32.4 & 0.0 & 100.0 & 54.8 \\
\hline Wood \& Paper & 26.6 & 33.3 & 32.7 & 33.3 & 28.6 & 33.3 & 0.0 & 15.3 & 20.1 \\
\hline Basic Intermediates & 14.6 & 16.2 & 16.2 & 16.7 & 50.0 & 24.3 & 0.0 & 24.1 & 14.6 \\
\hline Machinery \& Equipment & 17.7 & 23.8 & 24.1 & 24.6 & 86.8 & 24.1 & 0.0 & 15.3 & 15.2 \\
\hline Total & 18.0 & 24.5 & 11.9 & 21.5 & 93.9 & 16.8 & 0.0 & 46.0 & 12.9 \\
\hline \multicolumn{10}{|l|}{ Rest of SADC } \\
\hline & $\begin{array}{l}\text { South } \\
\text { Africa }\end{array}$ & Botswana & Malawi & Mozambique & Tanzania & Zambia & Zimbabwe & $\begin{array}{l}\text { Rest of } \\
\text { SADC }\end{array}$ & EU \\
\hline Grain & 0.2 & 0.0 & 0.0 & 0.0 & 0.0 & 0.0 & 2.1 & 0.0 & 0.5 \\
\hline Fruits \& Vegetables & 22.7 & 0.0 & 0.0 & 0.0 & 0.0 & 0.0 & 26.5 & 0.0 & 5.5 \\
\hline Other Agriculture & 15.4 & 0.0 & 0.0 & 0.0 & 0.0 & 0.0 & 28.8 & 0.0 & 13.1 \\
\hline Livestock & 1.8 & 0.0 & 0.0 & 0.0 & 0.0 & 0.0 & 0.0 & 0.0 & 2.5 \\
\hline Forestry \& Fisheries & 9.1 & 0.0 & 0.0 & 0.0 & 0.0 & 0.0 & 0.0 & 0.0 & 9.1 \\
\hline Energy \& Mines & 11.8 & 0.0 & 0.0 & 0.0 & 0.0 & 0.0 & 0.0 & 0.0 & 13.5 \\
\hline Food Processing & 44.9 & 0.0 & 0.0 & 0.0 & 22.5 & 0.0 & 7.0 & 0.0 & 29.6 \\
\hline Textiles & 6.1 & 0.0 & 0.0 & 0.0 & 0.0 & 0.0 & 0.0 & 0.0 & 1.5 \\
\hline Apparel & 58.0 & 0.0 & 0.0 & 0.0 & 0.0 & 0.0 & 16.7 & 0.0 & 34.5 \\
\hline Wood \& Paper & 27.6 & 0.0 & 0.0 & 0.0 & 0.0 & 0.0 & 11.1 & 0.0 & 47.1 \\
\hline Basic Intermediates & 22.0 & 0.0 & 0.0 & 0.0 & 0.0 & 0.0 & 59.1 & 0.0 & 22.9 \\
\hline Machinery \& Equipment & 32.4 & 0.0 & 0.0 & 0.0 & 57.1 & 0.0 & 21.3 & 0.0 & 28.0 \\
\hline Total & 26.6 & 0.0 & 0.0 & 0.0 & 17.8 & 0.0 & 14.5 & 0.0 & 23.9 \\
\hline \multicolumn{10}{|l|}{ EU } \\
\hline & $\begin{array}{l}\text { South } \\
\text { Africa }\end{array}$ & Botswana & Malawi & Mozambique & Tanzania & Zambia & Zimbabwe & $\begin{array}{l}\text { Rest of } \\
\text { SADC }\end{array}$ & EU \\
\hline Grain & 7.4 & 33.3 & 15.8 & 0.7 & 34.9 & 41.4 & 24.6 & 36.9 & 0.0 \\
\hline Fruits \& Vegetables & 17.2 & 25.0 & 14.1 & 14.8 & 63.3 & 14.7 & 14.9 & 30.5 & 0.0 \\
\hline Other Agriculture & 3.7 & 0.0 & 3.8 & 1.7 & 3.0 & 3.1 & 4.0 & 3.8 & 0.0 \\
\hline Livestock & 4.7 & 6.7 & 0.0 & 12.5 & 9.0 & 5.7 & 7.8 & 19.2 & 0.0 \\
\hline Forestry \& Fisheries & 11.1 & 0.0 & 3.2 & 8.1 & 0.8 & 0.8 & 3.7 & 2.2 & 0.0 \\
\hline Energy \& Mines & 0.0 & 0.1 & 0.0 & 0.0 & 0.0 & 0.0 & 0.0 & 0.0 & 0.0 \\
\hline Food Processing & 44.1 & 86.3 & 71.0 & 29.3 & 36.3 & 74.2 & 71.4 & 66.4 & 0.0 \\
\hline Textiles & 5.6 & 0.0 & 8.7 & 11.1 & 11.7 & 5.9 & 8.3 & 12.4 & 0.0 \\
\hline Apparel & 7.4 & 11.6 & 5.6 & 4.3 & 7.1 & 4.6 & 9.4 & 12.2 & 0.0 \\
\hline Wood \& Paper & 3.0 & 0.0 & 0.0 & 1.9 & 1.3 & 3.4 & 2.5 & 3.6 & 0.0 \\
\hline Basic Intermediates & 1.3 & 0.6 & 0.0 & 2.5 & 1.9 & 0.1 & 3.0 & 2.8 & 0.0 \\
\hline Machinery \& Equipment & 2.1 & 4.7 & 2.3 & 3.2 & 0.7 & 0.8 & 1.4 & 2.6 & 0.0 \\
\hline Total & 4.0 & 1.7 & 7.4 & 12.6 & 8.0 & 7.2 & 8.2 & 16.3 & 0.0 \\
\hline
\end{tabular}


Figure 3: Export Dependence on EU

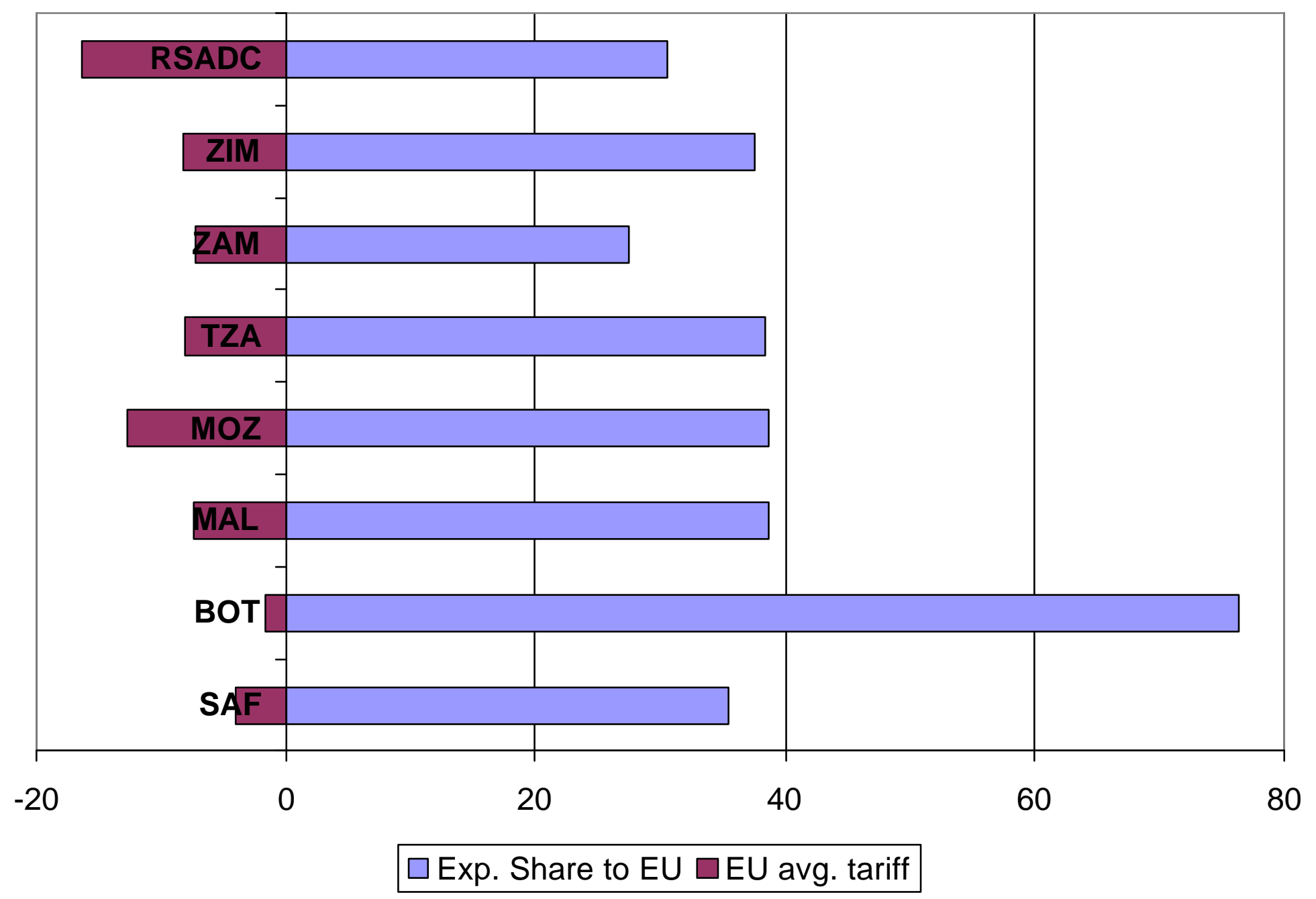


Figure 4: Export Dependence on South Africa

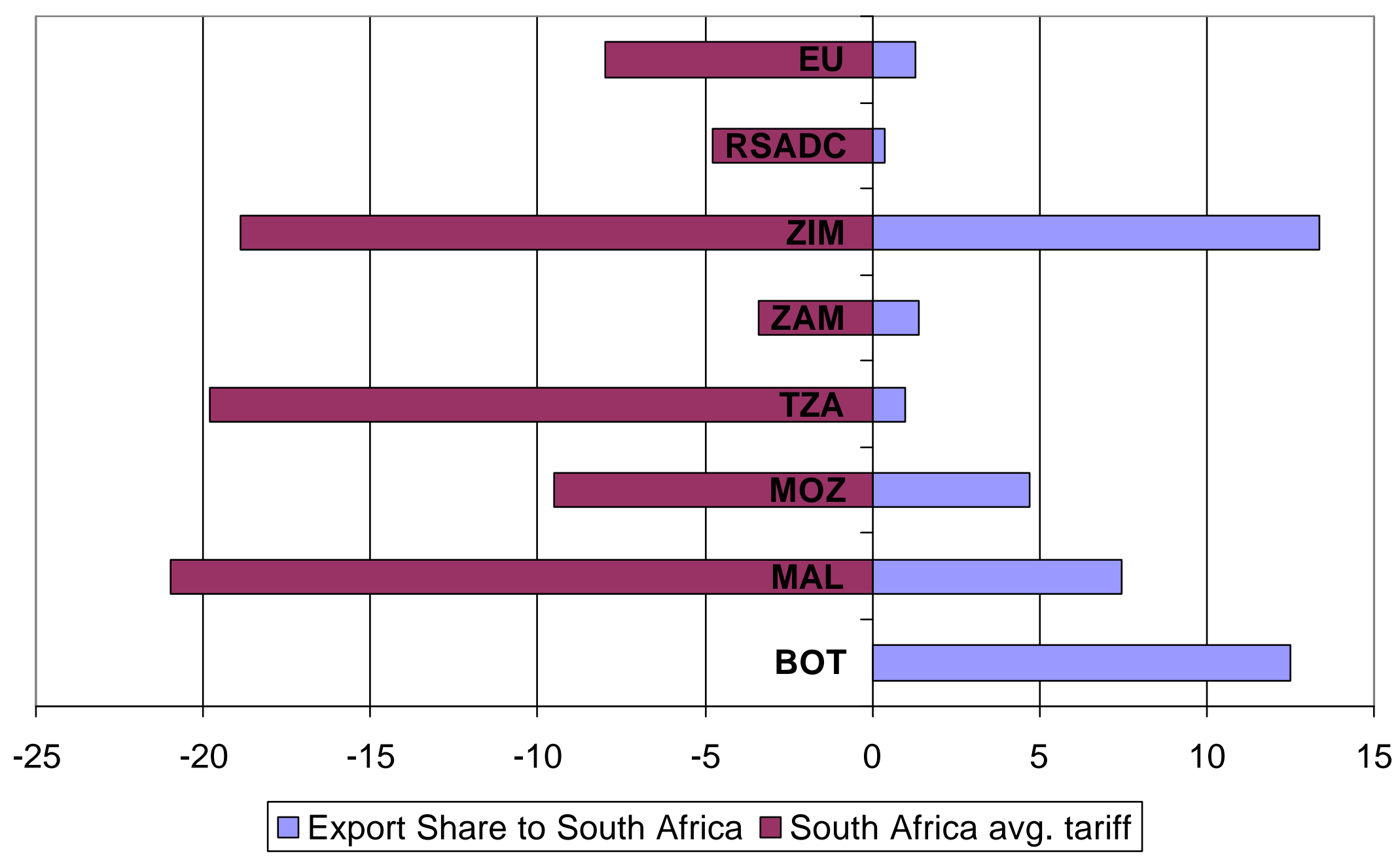


Figure 5: Percent Change in Real Absorption

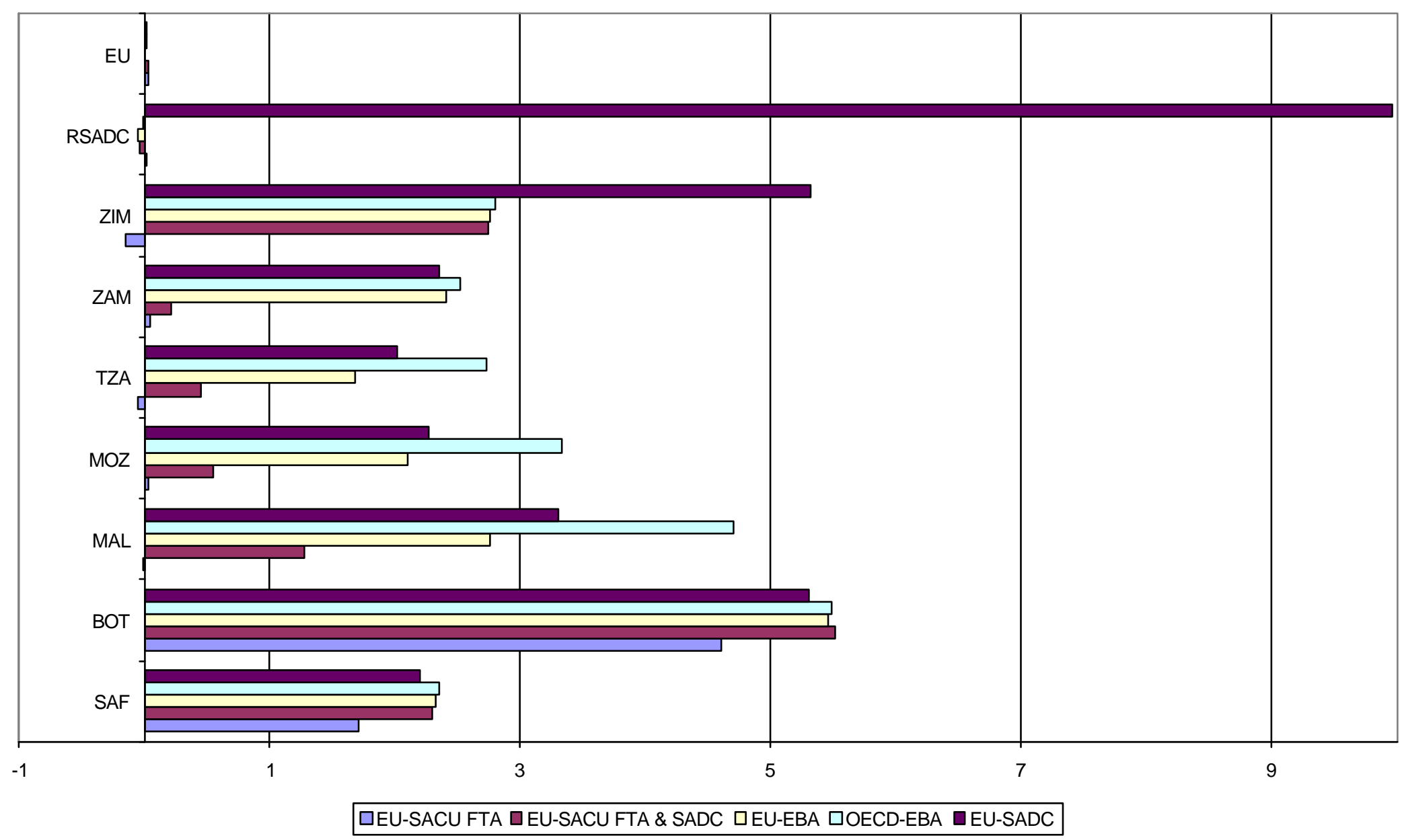


Figure 6: Percent Change in Real GDP

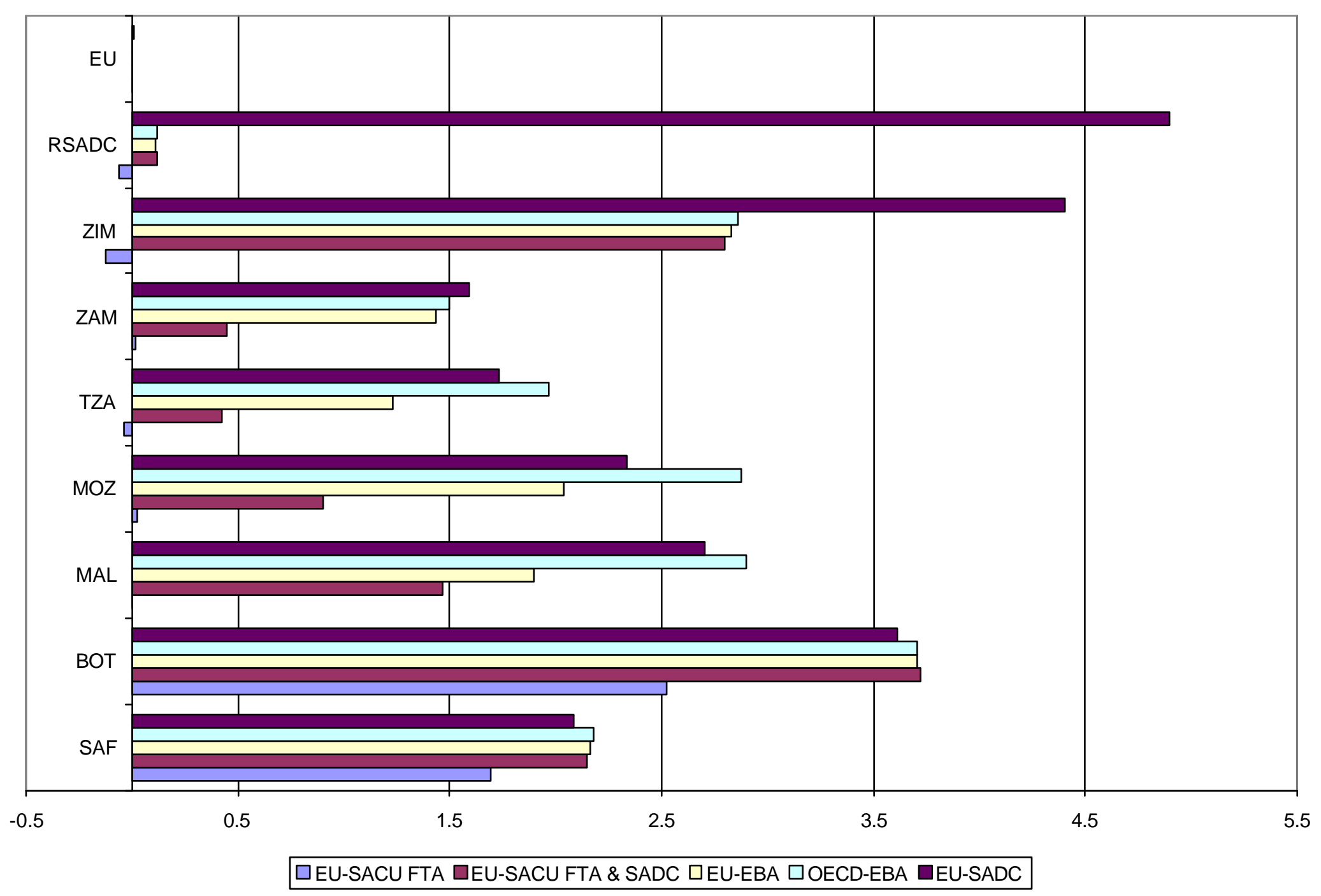


Figure 7: Percent Change in Unskilled Labor Supply

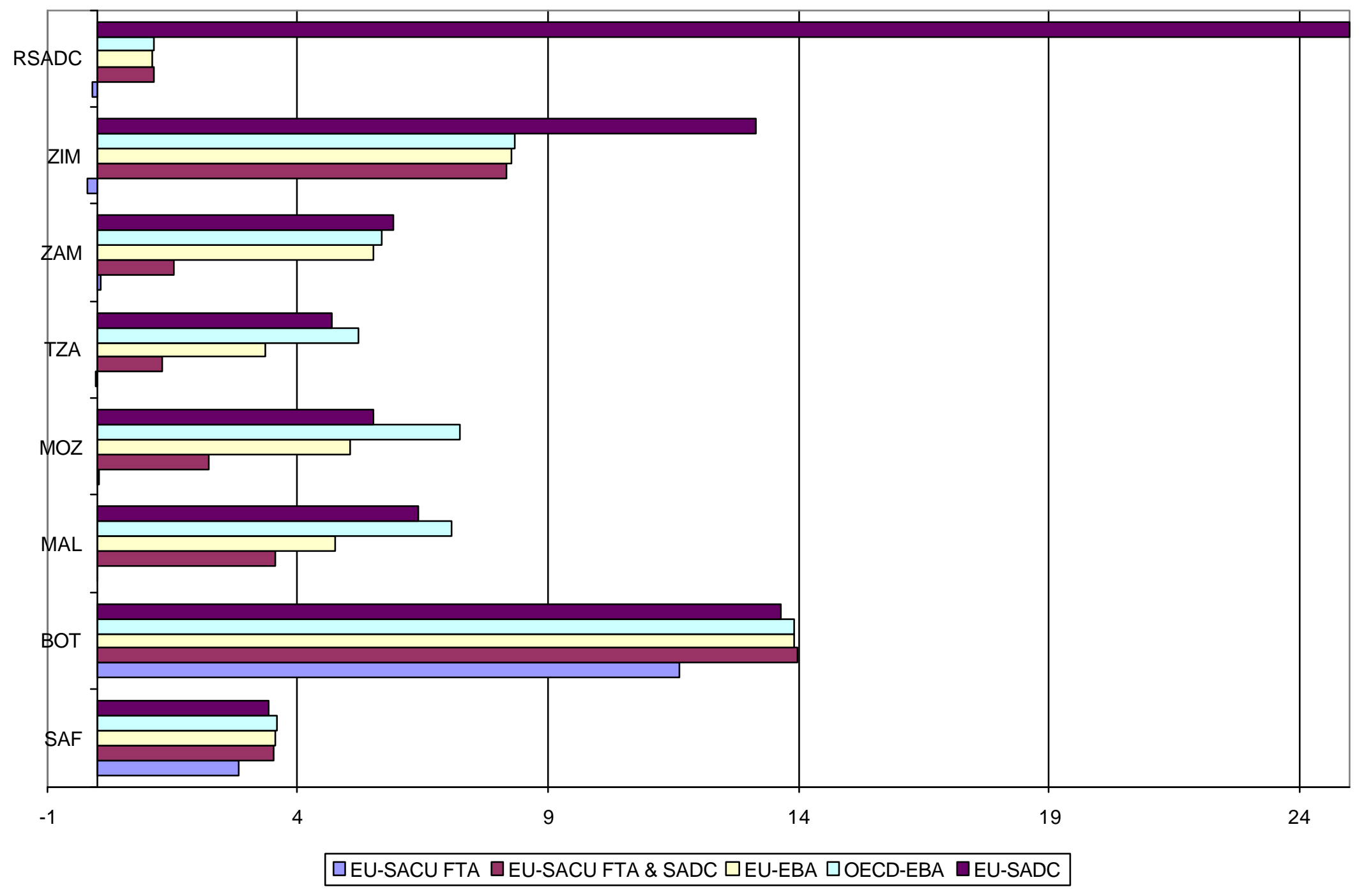


Figure 8: Percent Change in Total Exports

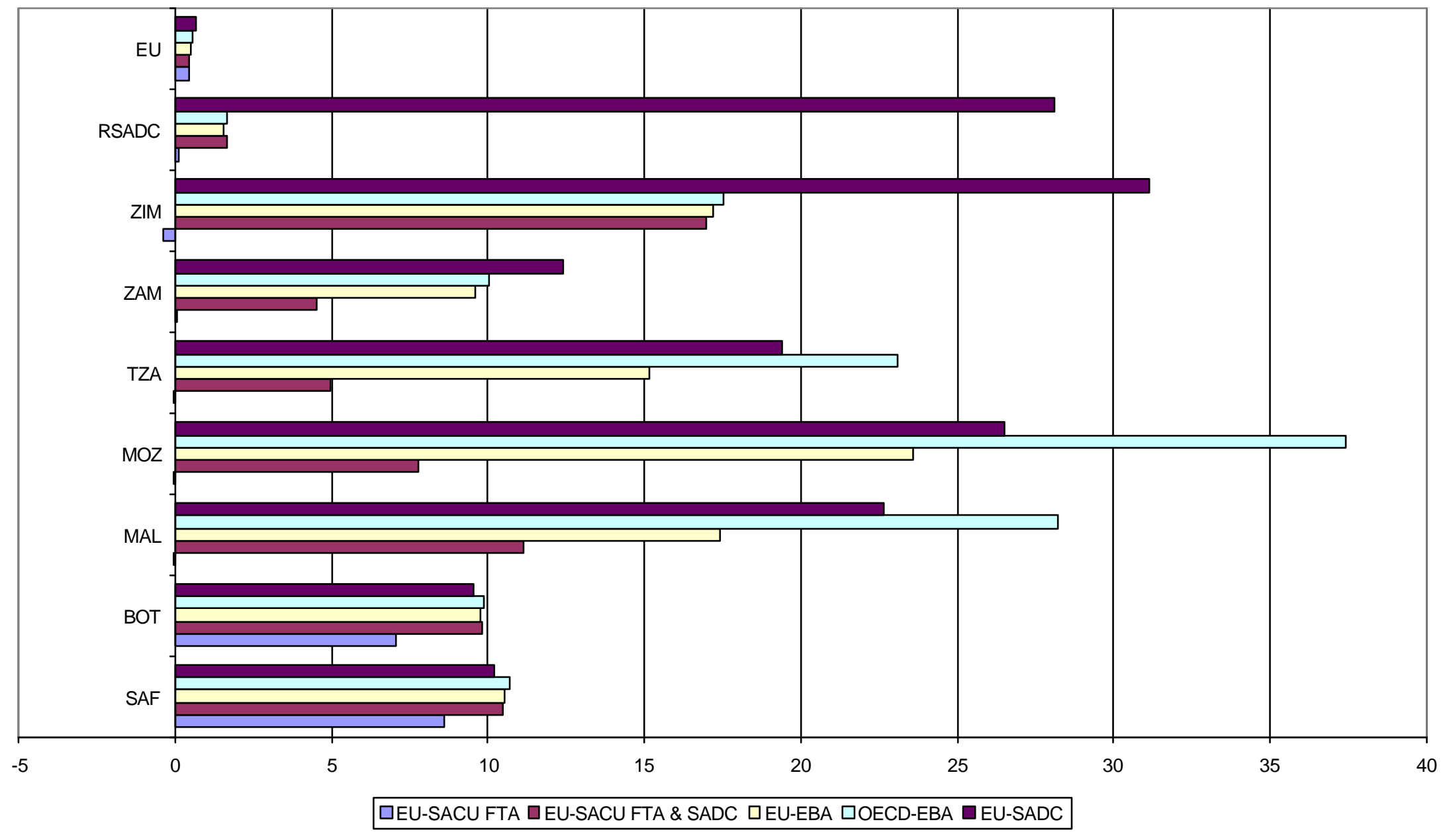


Figure 9: Trade Creation and Trade Diversion in South Africa, billions of US \$

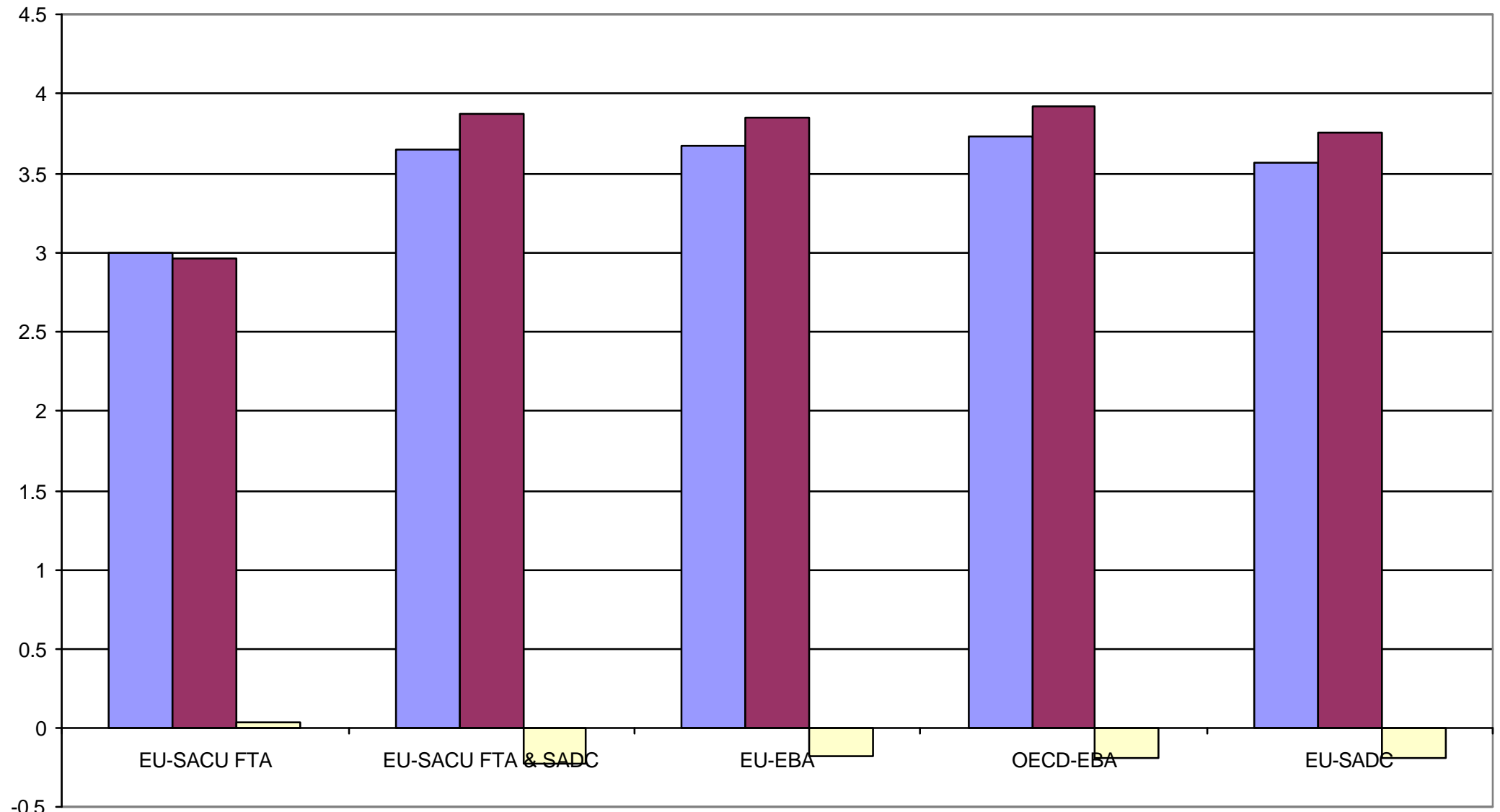

口Expand $\square$ Create QDivert 
Figure 10: Trade Creation and Diversion in Botswana, billions of US \$

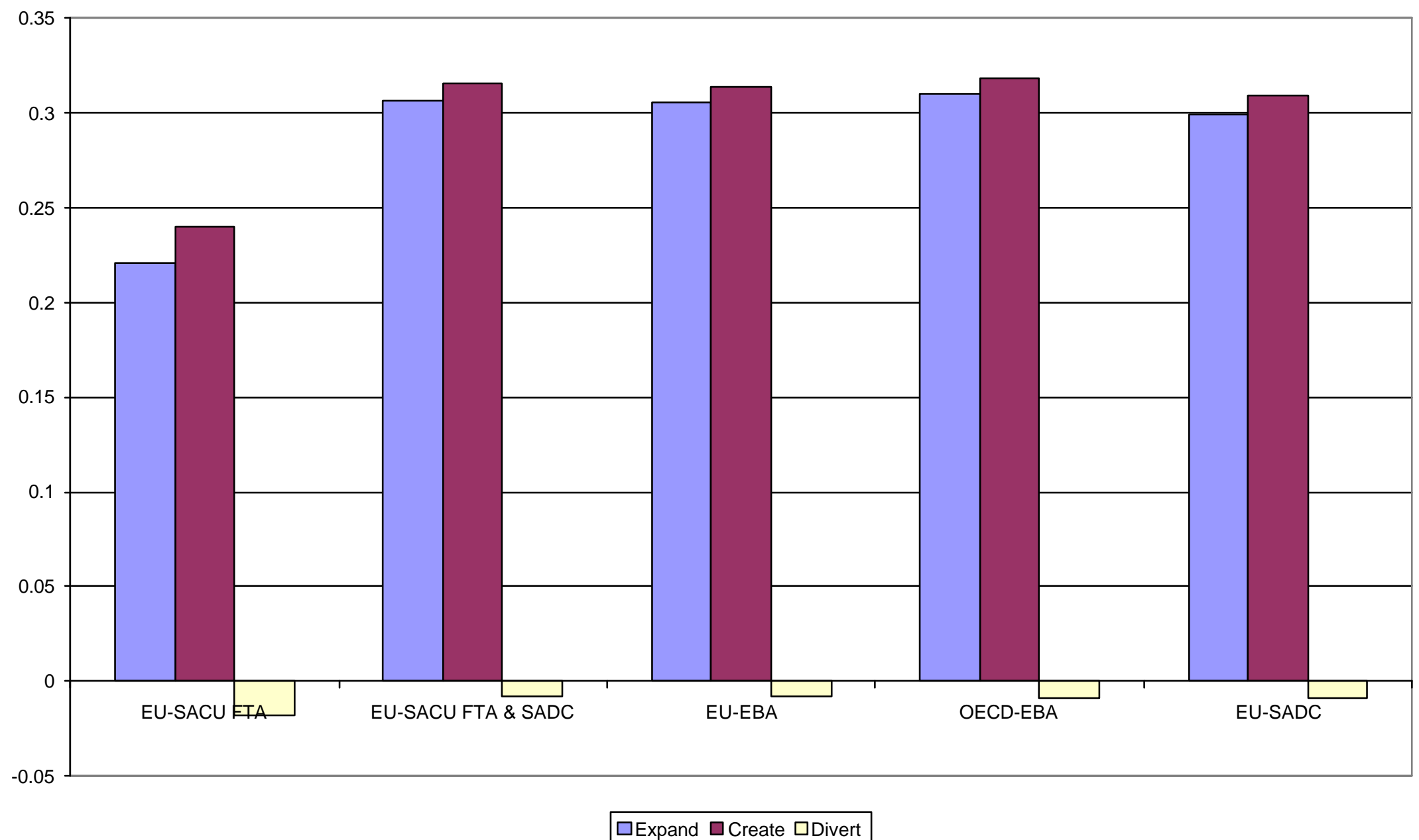


Figure 11: Trade Creation and Diversion in the EU, billions of US \$

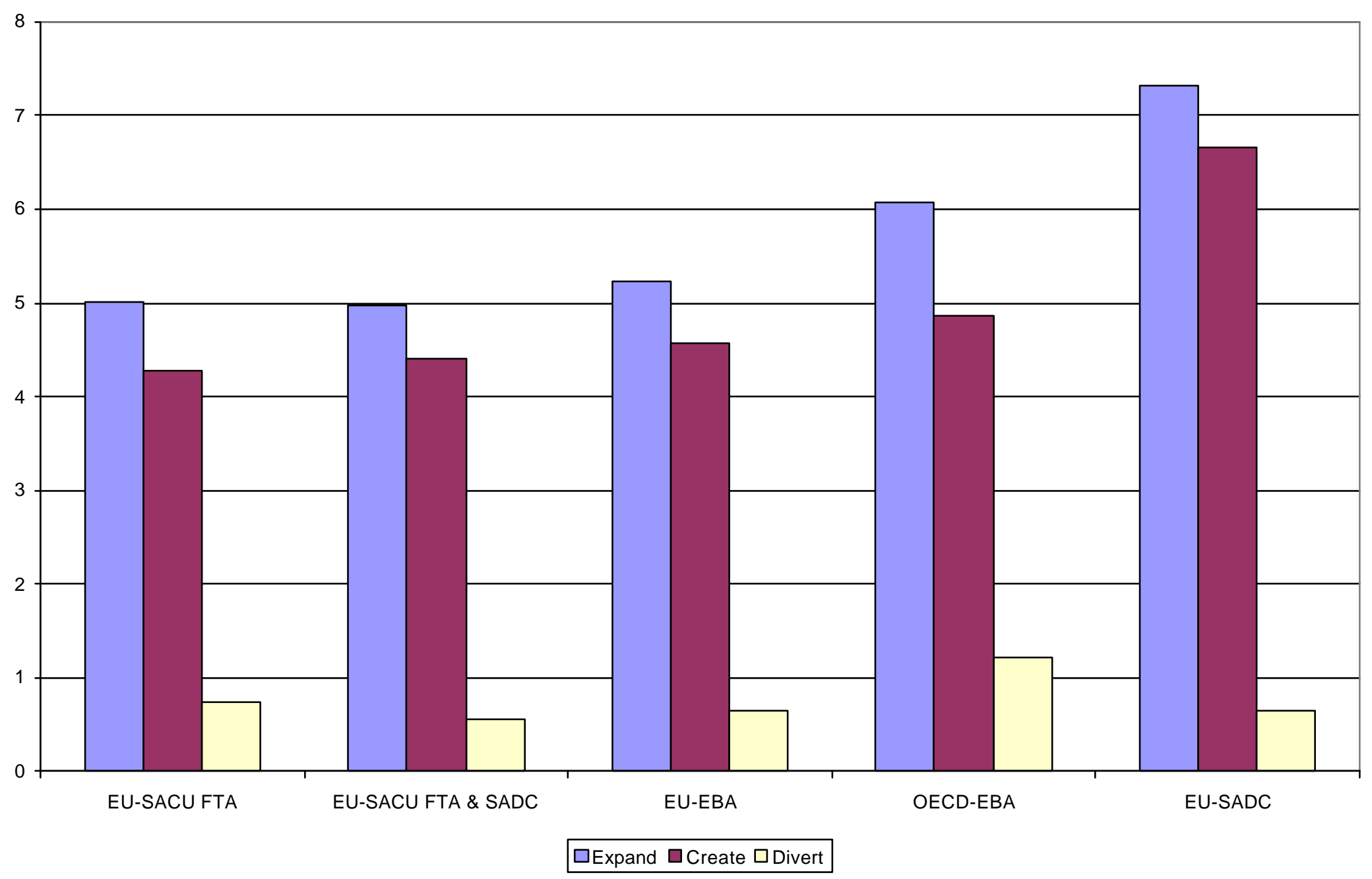


Figure 12: Percent Change in Real GDP, SADC Rules of Origin Sensitivity

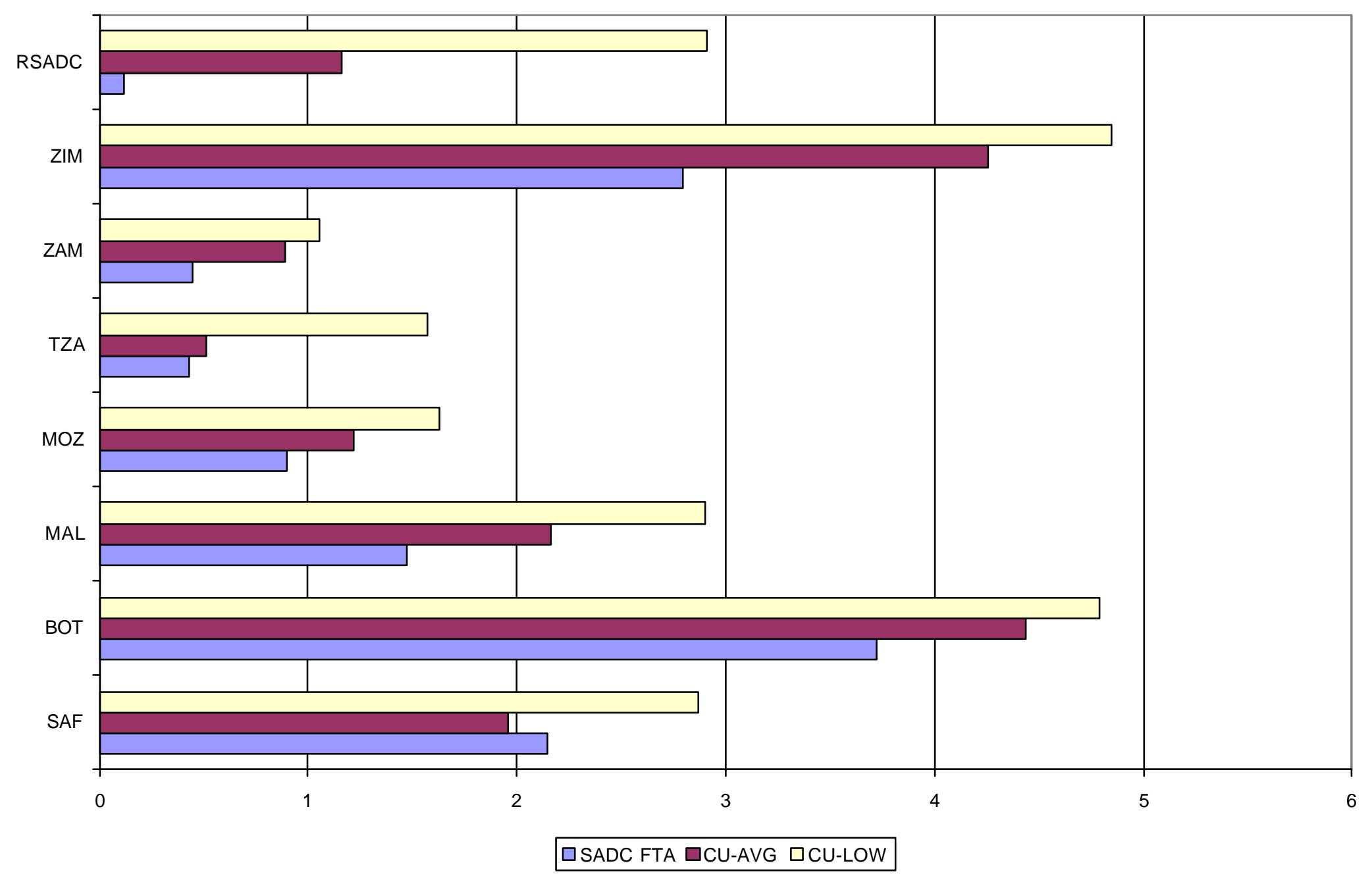


Figure 13: Trade Creation and Diversion in Malawi, billions of US $\$$

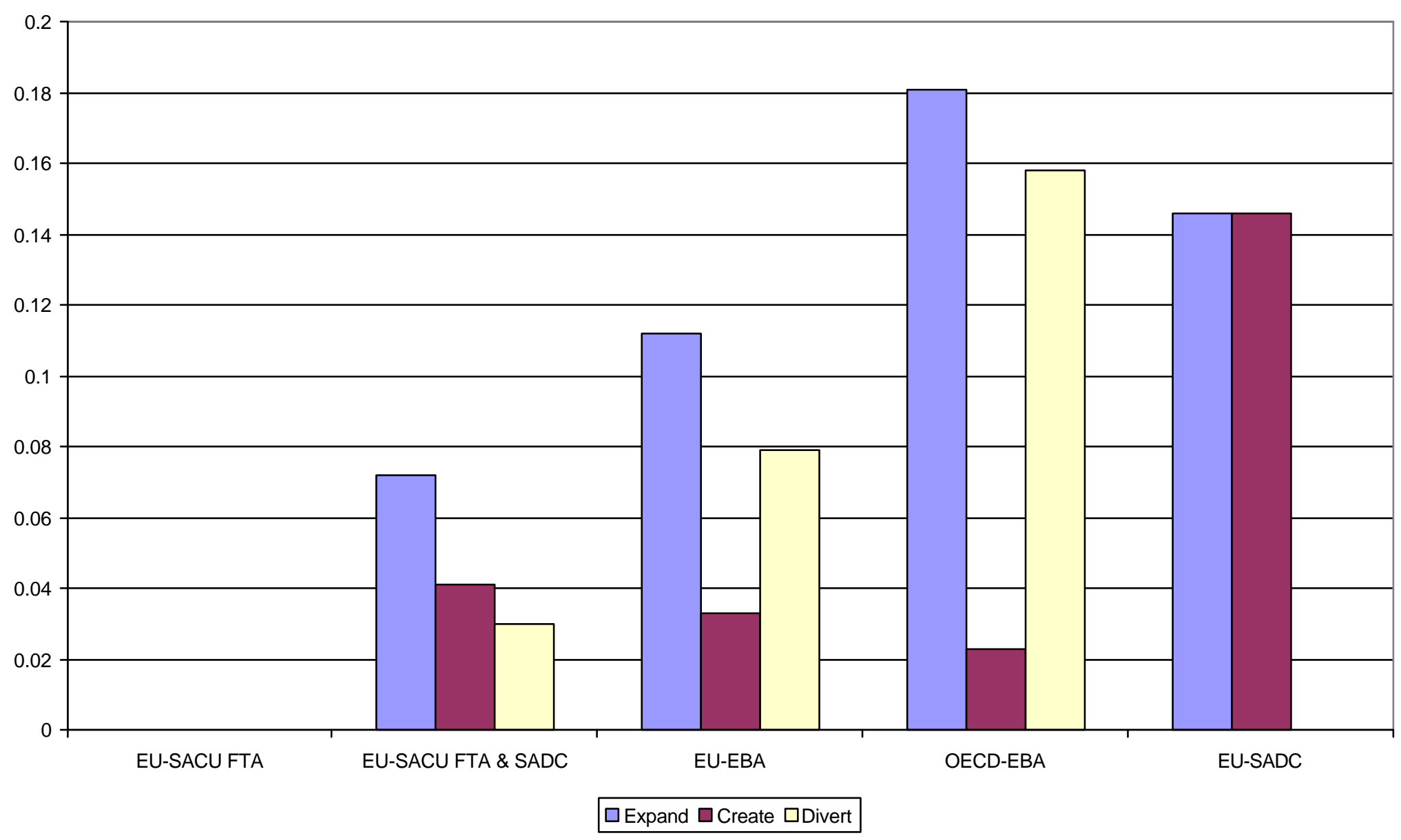


Figure 14: Trade Creation and Diversion in Tanzania, billions of US \$

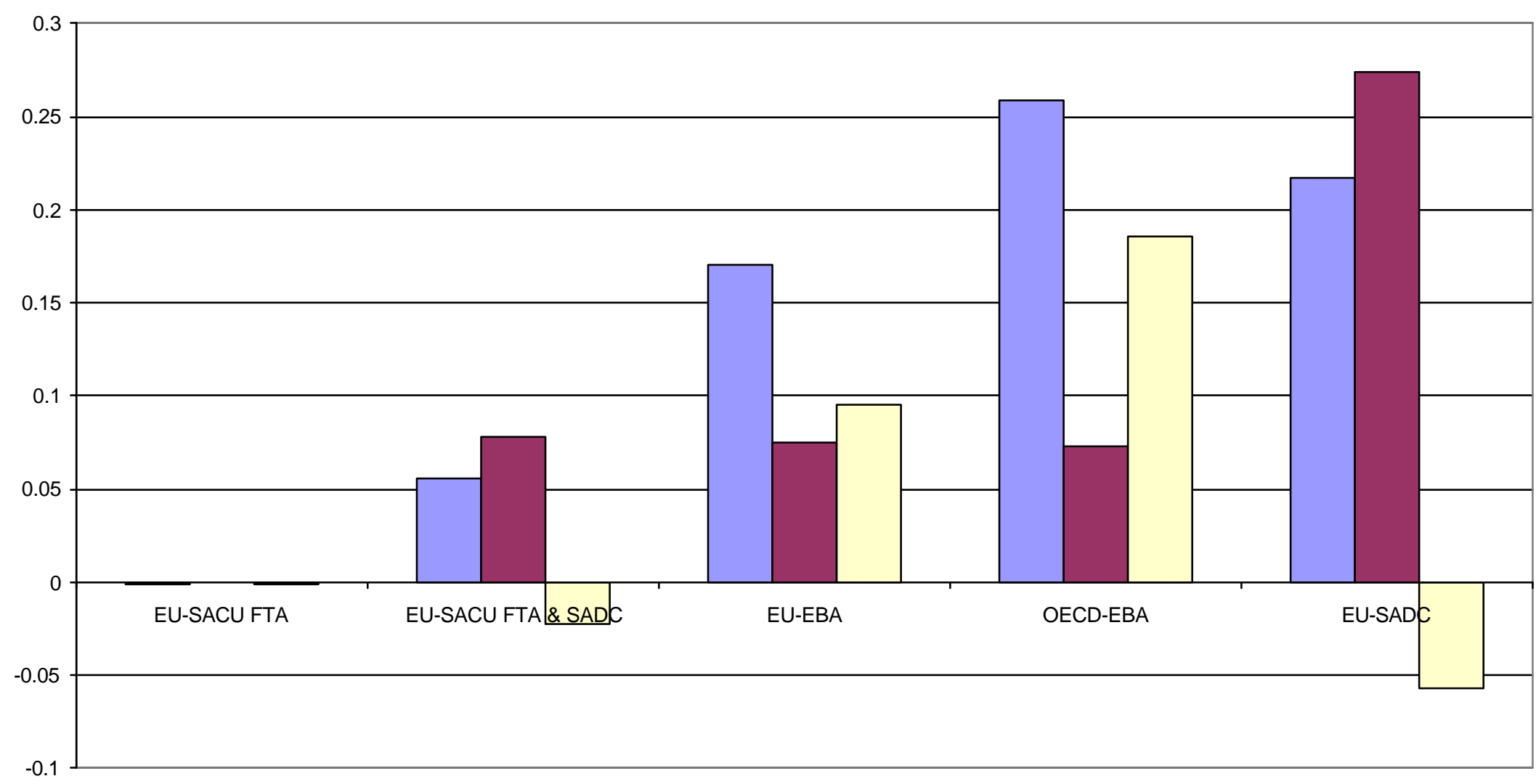

QExpand $\square$ Create $\square$ Divert 
Figure 15: Percent Change in Production, Malawi

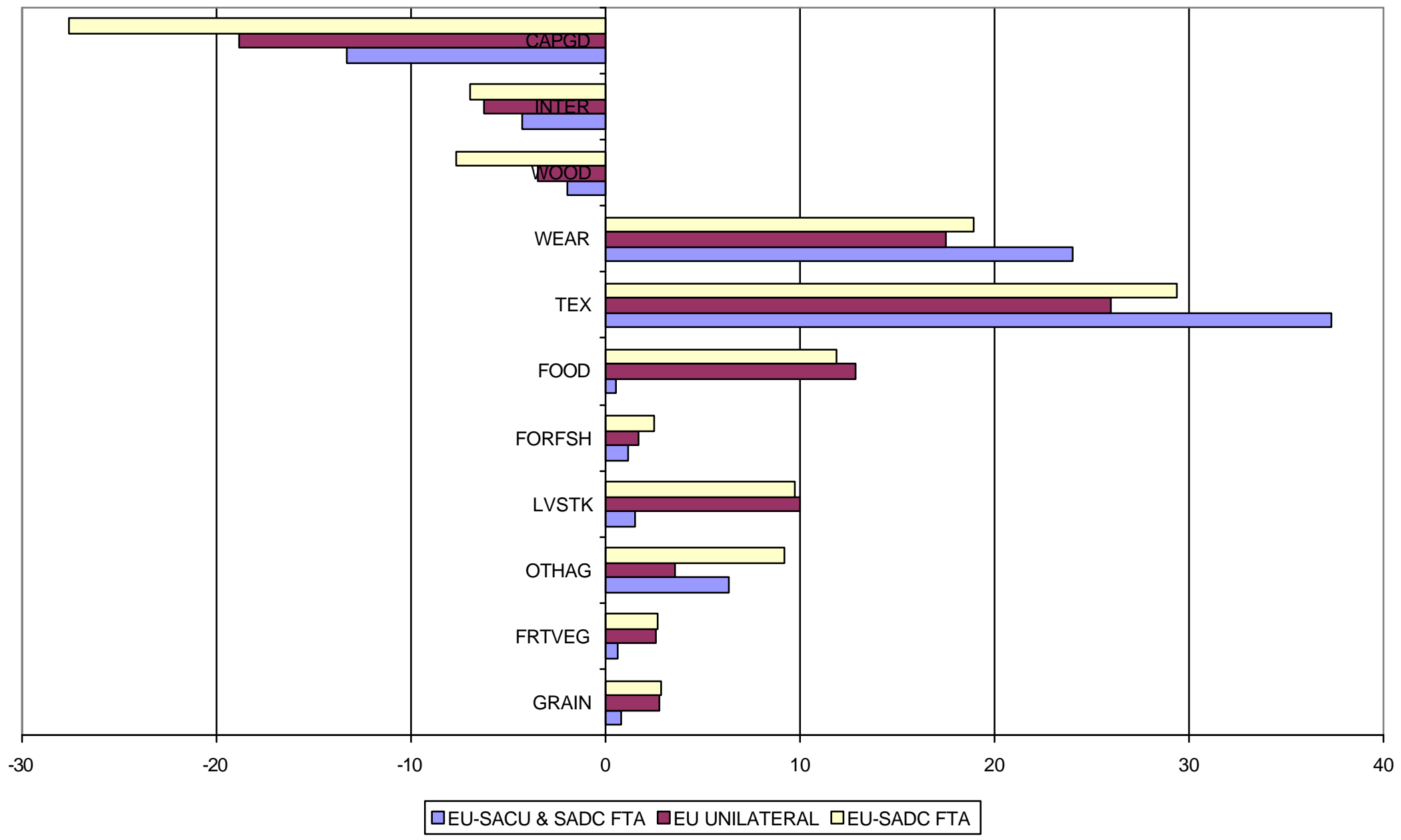


Figure 16: Percent Change in Production, Tanzania

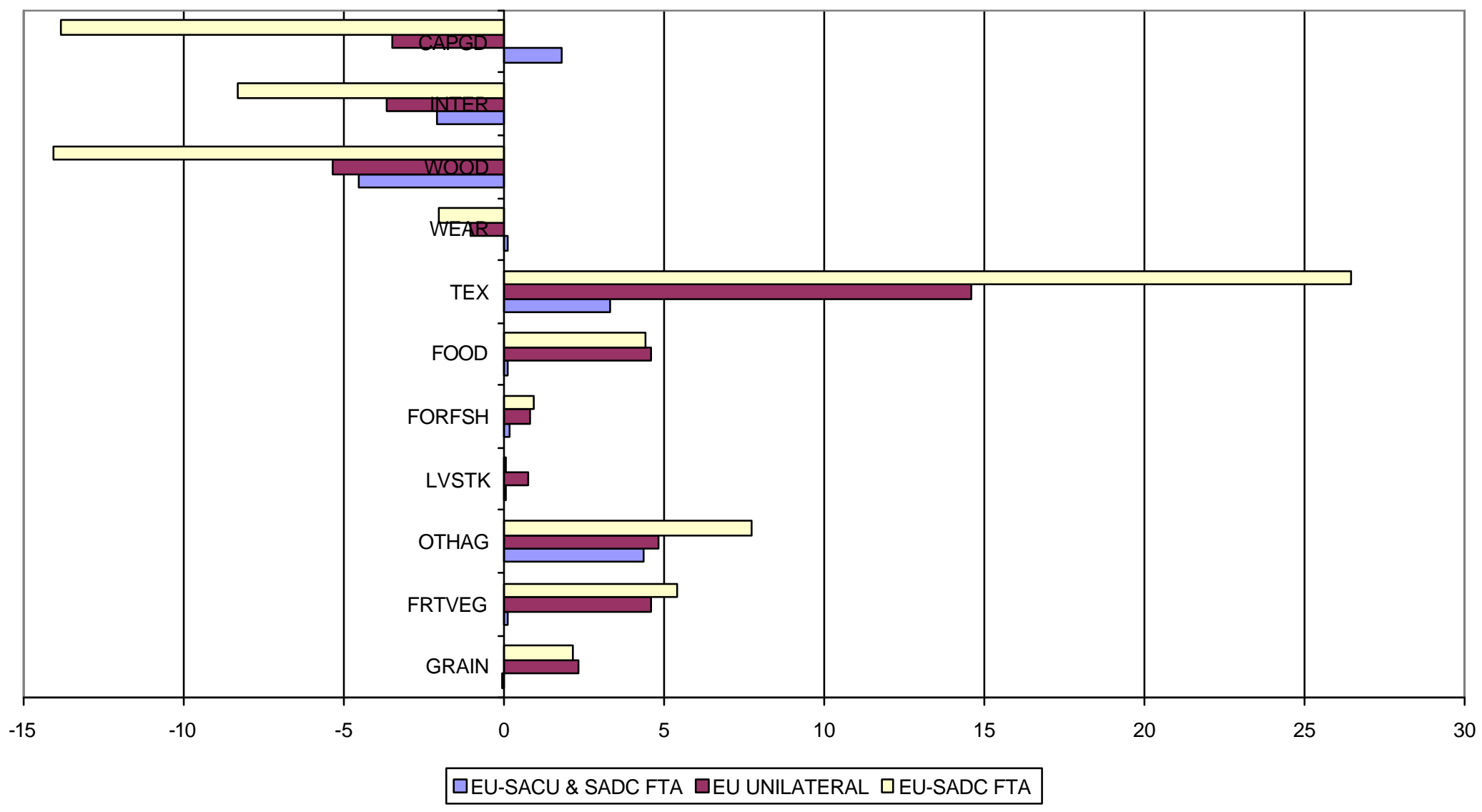




\section{List of Discussion Papers}

No. 40 - $\quad$ "Parameter Estimation for a Computable General Equilibrium Model: A Maximum Entropy Approach" by Channing Arndt, Sherman Robinson and Finn Tarp (February 1999)

No. 41 - "Trade Liberalization and Complementary Domestic Policies: A Rural-Urban General Equilibrium Analysis of Morocco" by Hans Löfgren, Moataz El-Said and Sherman Robinson (April 1999)

No. 42 - "Alternative Industrial Development Paths for Indonesia: SAM and CGE Analysis" by Romeo M. Bautista, Sherman Robinson and Moataz El-Said (May 1999)

No. 43* - "Marketing Margins and Agricultural Technology in Mozambique" by Channing Arndt, Henning Tarp Jensen, Sherman Robinson and Finn Tarp (July 1999)

No. 44 - $\quad$ "The Distributional Impact of Macroeconomic Shocks in Mexico: Threshold Effects in a Multi-Region CGE Model" by Rebecca Lee Harris (July 1999)

No. 45 - "Economic Growth and Poverty Reduction in Indochina: Lessons From East Asia" by Romeo M. Bautista (September 1999)

No. 46* - "After the Negotiations: Assessing the Impact of Free Trade Agreements in Southern Africa" by Jeffrey D. Lewis, Sherman Robinson and Karen Thierfelder (September 1999)

No. 47* - "Impediments to Agricultural Growth in Zambia" by Rainer Wichern, Ulrich Hausner and Dennis K. Chiwele (September 1999)

No. 48 - $\quad$ "A General Equilibrium Analysis of Alternative Scenarios for Food Subsidy Reform in Egypt" by Hans Lofgren and Moataz El-Said (September 1999)

No. 49*_ “A 1995 Social Accounting Matrix for Zambia” by Ulrich Hausner (September 1999) 
No. 50 - $\quad$ "Reconciling Household Surveys and National Accounts Data Using a Cross Entropy Estimation Method" by Anne-Sophie Robilliard and Sherman Robinson (November 1999)

No. 51 - " “Agriculture-Based Development: A SAM Perspective on Central Viet Nam” by Romeo M. Bautista (January 2000)

No. 52 - " "Structural Adjustment, Agriculture, and Deforestation in the Sumatera Regional Economy” by Nu Nu San, Hans Löfgren and Sherman Robinson (March 2000)

No. 53 - "Empirical Models, Rules, and Optimization: Turning Positive Economics on its Head" by Andrea Cattaneo and Sherman Robinson (April 2000)

No. 54 - "Small Countries and the Case for Regionalism vs. Multilateralism” by Mary E. Burfisher, Sherman Robinson and Karen Thierfelder (May 2000)

No. 55 - "Genetic Engineering and Trade: Panacea or Dilemma for Developing Countries" by Chantal Pohl Nielsen, Sherman Robinson and Karen Thierfelder (May 2000)

No. 56 - "An International, Multi-region General Equilibrium Model of Agricultural Trade Liberalization in the South Mediterranean NIC's, Turkey, and the European Union” by Ali Bayar, Xinshen Diao and A. Erinc Yeldan (May 2000)

No. 57* - "Macroeconomic and Agricultural Reforms in Zimbabwe: Policy Complementarities Toward Equitable Growth” by Romeo M. Bautista and Marcelle Thomas (June 2000)

No. 58 - "Updating and Estimating a Social Accounting Matrix Using Cross Entropy Methods ” by Sherman Robinson, Andrea Cattaneo and Moataz El-Said (August 2000)

No. 59 - "Food Security and Trade Negotiations in the World Trade Organization : A Cluster Analysis of Country Groups" by Eugenio Diaz-Bonilla, Marcelle Thomas, Andrea Cattaneo and Sherman Robinson (November 2000)

No. 60* - "Why the Poor Care About Partial Versus General Equilibrium Effects Part 1: Methodology and Country Case", by Peter Wobst (November 2000) 
No. 61 - "Growth, Distribution and Poverty in Madagascar : Learning from a

Microsimulation Model in a General Equilibrium Framework" by Denis Cogneau and Anne-Sophie Robilliard (November 2000)

No. 62 - "Farmland Holdings, Crop Planting Structure and Input Usage: An Analysis of China's Agricultural Census" by Xinshen Diao, Yi Zhang and Agapi Somwaru (November 2000)

No. 63 - "Rural Labor Migration, Characteristics, and Employment Patterns: A Study Based on China's Agricultural Census" by Francis Tuan, Agapi Somwaru and Xinshen Diao (November 2000)

No. 64 - "GAMS Code for Estimating a Social Accounting Matrix (SAM) Using Cross Entropy (CE) Methods" by Sherman Robinson and Moataz El-Said (December 2000)

No. 65 - “A Computable General Equilibrium Analysis of Mexico’s Agricultural Policy Reforms” by Rebecca Lee Harris (January 2001)

No. 66 - "Distribution and Growth in Latin America in an Era of Structural Reform" by Samuel A. Morley (January 2001)

No. 67 - "What has Happened to Growth in Latin America" by Samuel A. Morley (January 2001)

No. 68 - “China’s WTO Accession: Conflicts with Domestic Agricultural Policies and Institutions” by Hunter Colby, Xinshen Diao and Francis Tuan (January 2001)

No. 69 - “A 1998 Social Accounting Matrix for Malawi” by Osten Chulu and Peter Wobst (February 2001)

No. 70 - “A CGE Model for Malawi: Technical Documentation” by Hans Löfgren (February 2001)

No. 71 - "External Shocks and Domestic Poverty Alleviation: Simulations with a CGE Model of Malawi” by Hans Löfgren with Osten Chulu, Osky Sichinga, Franklin Simtowe, Hardwick Tchale, Ralph Tseka and Peter Wobst (February 2001)

No. 72 - "Less Poverty in Egypt? Explorations of Alternative Pasts with Lessons for the Future" Hans Löfgren (February 2001) 
No. 73 - "Macro Policies and the Food Sector in Bangladesh: A General Equilibrium Analysis" Marzia Fontana, Peter Wobst and Paul Dorosh (February 2001)

No. 74 - "A 1993-94 Social Accounting Matrix with Gender Features for Bangladesh" Marzia Fontana and Peter Wobst (April 2001)

No. 75 - “A Standard Computable General Equilibrium (CGE) Model in” Hans Löfgren, Rebecca Lee Harris and Sherman Robinson (April 2001)

No. 76 - "A Regional General Equilibrium Analysis of the Welfare Impact of Cash Transfers: An Analysis of Progresa in Mexico" David P. Coady and Rebecca Lee Harris (June 2001)

No. 77 - "Genetically Modified Foods, Trade, and Developing Countries" Chantal Pohl Nielsen, Karen Thierfelder and Sherman Robinson (August 2001)

No. 78 - "The Impact of Alternative Development Strategies on Growth and Distribution: Simulations with a Dynamic Model for Egypt" Moataz El-Said, Hans Löfgren and Sherman Robinson (September 2001)

No. 79 - "Impact of MFA Phase-Out on the World Economy an Intertemporal, Global General Equilibrium Analysis" Xinshen Diao and Agapi Somwaru (October 2001)

No. 80* - "Free Trade Agreements and the SADC Economies" Jeffrey D. Lewis, Sherman Robinson and Karen Thierfelder (November 2001)

TMD Discussion Papers marked with an '*' are MERRISA-related. Copies can be obtained by calling Maria Cohan at 202-862-5627 or e-mail: m.cohan@cgiar.org 